\title{
Retrograde metamorphism in a regional shear zone and related chemical changes: The Kaplice Unit of muscovite-biotite gneisses in the Moldanubian Zone of southern Bohemia, Czech Republic
}

\author{
Retrográdní metamorfóza muskovit-biotitických rul v kaplické jednotce moldanubika \\ jižních Čech a sdružené chemické změny
}

\author{
(11 figs, 7 tabs) \\ STANISLAV VRÁNA ${ }^{1}-$ JIŘI BÁRTEK² \\ ${ }^{1}$ clo Czech Geological Survey, Klárov 3, 11821 Praha 1 \\ 2 Alberta Energy and Utilities Board, Calgary, Alberta, Canada
}

\begin{abstract}
The geochemistry and petrology of the Kaplice Unit, a regional zone of muscovite-biotite gneisses $55 \times 8 \mathrm{~km}$ in size, was studied. Geochemistry of the gneisses is characterized using 27 samples for major element analyses and 15 samples for minor and trace element analyses. The data are compared with element abundances in gneisses of the adjacent Monotonous and Variegated Units, with the aim to define respective chemical differences. $\mathrm{K}, \mathrm{Rb}, \mathrm{Cs}, \mathrm{Ba}, \mathrm{H}_{2} \mathrm{O}^{+}$and $\mathrm{Fe}_{2} \mathrm{O}_{3} / \mathrm{FeO}$ are significantly enriched and $\mathrm{Na}, \mathrm{Ca}, \mathrm{Sr}, \mathrm{P}$ and $\mathrm{U}$ are distinctly depleted in comparison to biotite gneisses of both the Monotonous and the Variegated Units; the ratio $\mathrm{Rb} / \mathrm{Sr}$ increased by a factor of 3.5. The contents of Ti, Al, Fet, Mg, Cr, Ce, Y, Hf, Ta and Th are closely comparable, which corresponds to behaviour of relatively immobile elements. Extensive hydration was accompanied by significant oxidation and other chemical changes comparable to synmetamorphic acid leaching. Microstructural relations indicate sillimanite- and K-feldspar-consuming reactions producing muscovite intergrown with biotite in recrystallized quartz-feldspar fabric. Residual sillimanite occurs as minute aggregates armoured by muscovite. Abundant quartz segregation lenses aligned in the dominant S3 foliation indicate high silica activity and carry occassional large crystals of andalusite, rare kyanite, cordierite or rutile. Concurrent reactions in calc-silicate gneiss interbands resulted in replacement of diopside by actinolite or low-Al magnesiohornblende and partial replacement of anorthite by clinozoisite \pm minor garnet. Structural and petrological data indicate that the unit represents a regional shear zone (D3 planar foliation sets), functioning as a major conduit with a high, synmetamorphic fluid flux in the NW roof domain of the Moldanubian Pluton in southern Bohemia. Since the intrusion of the Eisgarn pluton post-dates the S3 planar fabric and largely pre-dates extension D4 crenulation, it is possible that the cooling two-mica granite body, structurally underlying the Kaplice Unit, served as a source of fluids, important in the retrograde alteration of paragneisses and the accompanying chemical changes.
\end{abstract}

Key words: retrograde metamorphism; regional shear zone; polyphase deformation; paragneiss geochemistry; Moldanubian Zone; Bohemian Massif

\section{Introduction}

Muscovite-biotite gneisses carrying substantial amounts of muscovite are confined to several domains in the Moldanubian Zone of the Bohemian Massif, dominated typically by amphibolite-facies gneisses and migmatites in sillimanite-K-feldspar zone and some granulite bodies. They include the following: (a) the Kaplice Unit in southern Bohemia, (b) the mica schist zone at the eastern margin of the Moldanubian Zone, along contact with the Moravo-Silesian Zone, (c) the Chýnov Unit of muscovite-biotite gneisses east and northeast of Tábor in central Bohemia, (d) the Královský Hvozd Unit in southwestern Bohemia, (e) the Rataje mica schist zone (Koutek 1933, Kachlík 1999). Comparison of information on structure and petrology (Vrána et al. 1995, Kachlík 1999, Babůrek 2003) indicates that the above units show differences in deformation and polyphase metamorphism history. Consequently, each of these domains should be considered separately.

The muscovite-biotite gneisses of the Kaplice Unit were interpreted both as retrograde rocks derived from former sillimanite-biotite gneisses (Zelenka 1926) and as prograde rocks, preserving the early, relatively low-grade record (Pletánek - Suk 1976, Bártek 1979). Systematic new mapping and the accompanying structural and pet- rological work by geologists of the Czech Geological Survey during the years 1976-1987 resulted in complete coverage of the Kaplice Unit by published maps on the scale $1: 25000$ with explanations (Fig. 1). The information indicates that the unit represents a major regional zone of monoclinal D3 shearing, accompanied by retrograde metamorphism. This paper presents chemical information on gneisses of the Kaplice Unit and examines chemical changes that probably accompanied a high-rate fluid flux in the regional shear zone. As these aspects of evolution of the Kaplice Unit are closely tied to structural setting, data on structural relations are briefly introduced.

The retrograde metamorphic reactions in calc-silicate gneisses resulting in replacement of diopside + anorthite by actinolite + clinozoisite $( \pm$ garnet) are also documented.

\section{Data sets, samples and methods}

The geological and petrological information, serving as a basis for discussion of petrogenesis and chemical composition of gneisses was obtained largely by mapping on the scale $1: 25000$ and the accompanying structural and petrological work.

The major elements were analyzed by methods of wet analyses in the Chemical laboratory of the Czech Geo- 


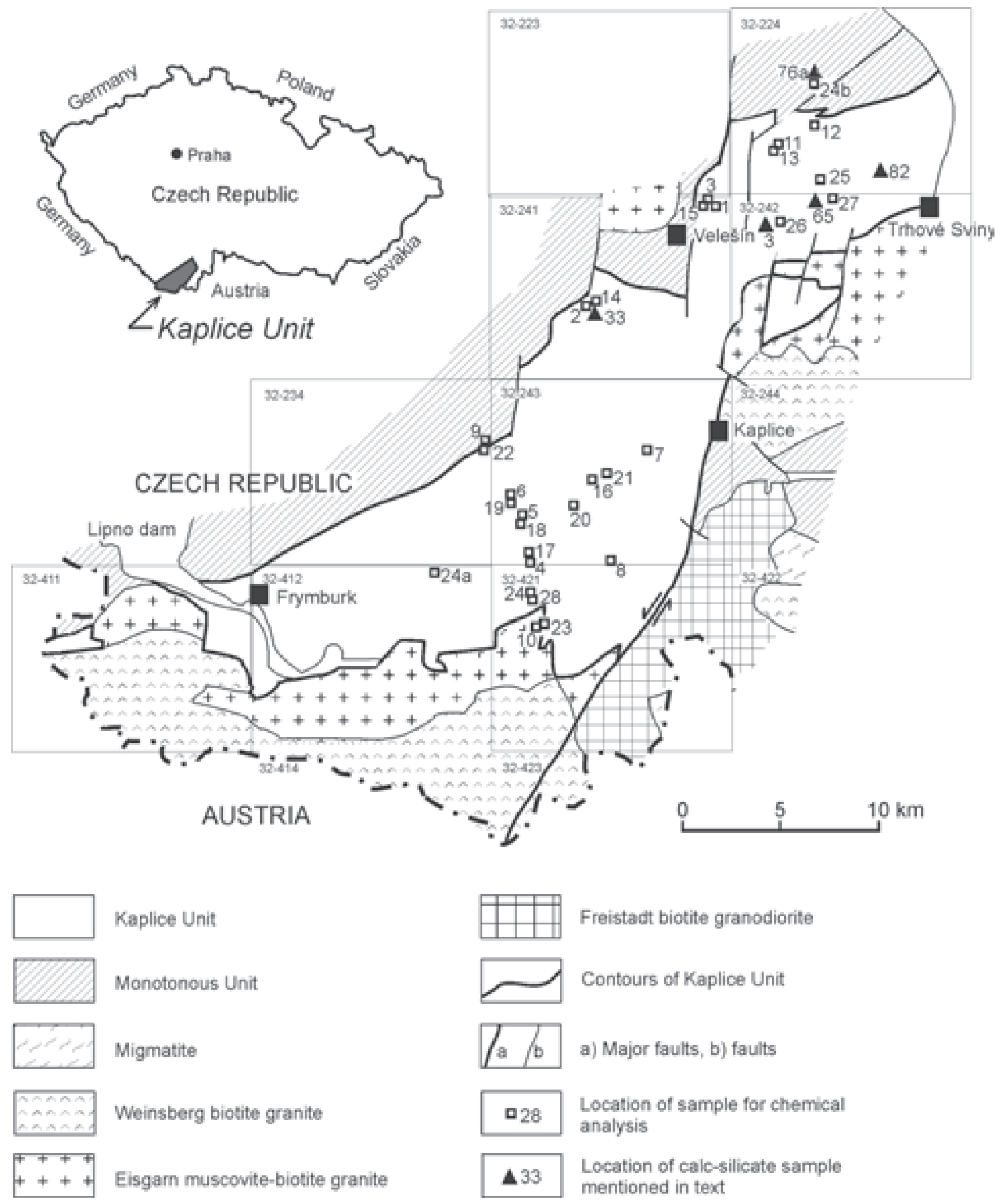

Fig. 1. Sketch map of the Kaplice Unit showing location of the analyzed samples and numbers of $1: 25000$ map sheets published by the Czech Geological Survey. 
Table 1. Chemical analyses of K-rich muscovite-biotite gneisses, Kaplice Unit.

\begin{tabular}{|c|c|c|c|c|c|c|c|c|c|c|c|c|}
\hline Sample No. & 1 & 2 & 3 & 4 & 5 & 6 & 7 & 8 & 10 & 16 & 20 & 24 \\
\hline $\mathrm{SiO}_{2}$ & 64.00 & 55.36 & 66.83 & 62.52 & 60.89 & 64.69 & 60.12 & 54.54 & 59.98 & 69.14 & 58.98 & 62.66 \\
\hline $\mathrm{TiO}_{2}$ & 0.72 & 1.00 & 0.86 & 0.90 & 0.78 & 0.78 & 0.70 & 0.71 & 0.90 & 0.65 & 0.80 & 0.81 \\
\hline $\mathrm{Al}_{2} \mathrm{O}_{3}$ & 16.97 & 21.07 & 16.41 & 17.38 & 17.83 & 16.07 & 17.83 & 22.58 & 18.93 & 14.75 & 19.01 & 17.89 \\
\hline $\mathrm{Fe}_{2} \mathrm{O}_{3}$ & 1.01 & 2.58 & 1.36 & 1.72 & 2.12 & 1.99 & 3.17 & 2.89 & 0.75 & 1.13 & 1.45 & 1.81 \\
\hline $\mathrm{FeO}$ & 4.65 & 4.79 & 4.03 & 4.00 & 4.26 & 3.55 & 4.55 & 4.95 & 3.98 & 3.20 & 5.25 & 3.70 \\
\hline MnO & 0.06 & 0.10 & 0.08 & 0.04 & 0.15 & 0.05 & 0.10 & 0.08 & 0.04 & 0.07 & 0.09 & 0.04 \\
\hline MgO & 2.40 & 2.85 & 2.10 & 2.61 & 3.22 & 2.19 & 2.70 & 2.45 & 3.22 & 1.92 & 3.54 & 2.04 \\
\hline $\mathrm{CaO}$ & 0.70 & 0.86 & 0.38 & 0.67 & 0.71 & 0.67 & 0.75 & 0.28 & 1.10 & 0.58 & 0.76 & 0.71 \\
\hline $\mathrm{Li}_{2} \mathrm{O}$ & 0.010 & n.d. & 0.006 & 0.014 & 0.009 & 0.007 & n.d. & n.d. & 0.042 & 0.006 & 0.010 & 0.025 \\
\hline $\mathrm{Na}_{2}^{2} \mathrm{O}$ & 1.40 & 1.76 & 1.14 & 1.10 & 1.43 & 1.54 & 1.53 & 1.46 & 1.78 & 1.80 & 1.79 & 2.08 \\
\hline $\mathrm{K}_{2} \mathrm{O}$ & 3.79 & 5.72 & 3.42 & 4.70 & 3.98 & 4.70 & 4.14 & 5.18 & 5.18 & 3.86 & 4.20 & 4.22 \\
\hline $\mathrm{P}_{2} \mathrm{O}_{5}$ & 0.17 & 0.25 & 0.18 & 0.14 & 0.13 & 0.19 & 0.15 & 0.12 & 0.11 & 0.19 & 0.17 & 0.17 \\
\hline $\mathrm{CO}_{2}$ & 0.130 & 0.020 & 0.005 & 0.020 & 0.037 & 0.014 & n.d. & n.d. & 0.010 & 0.005 & 0.006 & 0.010 \\
\hline $\mathrm{C}^{2}$ & 0.030 & n.d. & 0.020 & 0.160 & n.d. & n.d. & n.d. & n.d. & n.d. & 0.130 & 0.026 & n.d. \\
\hline $\mathbf{F}$ & 0.07 & n.d. & 0.05 & 0.07 & 0.10 & 0.10 & n.d. & n.d. & 0.04 & 0.05 & 0.08 & 0.06 \\
\hline Cl & 0.01 & n.d. & 0.01 & 0.01 & 0.01 & 0.02 & n.d. & n.d. & 0.01 & 0.02 & 0.03 & 0.01 \\
\hline $\mathbf{S}$ & 0.010 & 0.007 & 0.005 & 0.005 & 0.010 & 0.010 & n.d. & n.d. & 0.010 & 0.010 & 0.010 & 0.010 \\
\hline $\mathrm{H}_{2} \mathrm{O}^{+}$ & 3.31 & 3.31 & 3.00 & 3.07 & 3.76 & 2.65 & 3.08 & 3.62 & 2.78 & 1.90 & 3.30 & 2.87 \\
\hline $\mathrm{H}_{2}^{2} \mathrm{O}^{-}$ & 0.12 & 0.28 & 0.33 & 0.31 & 0.27 & 0.52 & 0.49 & 0.41 & 0.22 & 0.21 & 0.24 & 0.32 \\
\hline -F ekv. & 0.03 & - & 0.02 & 0.03 & 0.04 & 0.04 & - & - & 0.02 & 0.02 & 0.03 & 0.02 \\
\hline Total & 99.53 & 99.96 & 100.20 & 99.41 & 99.66 & 99.70 & 99.31 & 99.27 & 99.06 & 99.60 & 99.71 & 99.42 \\
\hline \multicolumn{13}{|c|}{ Minor and trace elements } \\
\hline Sc & & & & 19.3 & 19.7 & 17.4 & & & 19.4 & 13.7 & 23.8 & 16.3 \\
\hline $\mathbf{V}$ & & & & 99.0 & 86.0 & 77.0 & & & 97.0 & 54.0 & 95.0 & 71.0 \\
\hline $\mathrm{Cr}$ & & & & 93.0 & 88.0 & 77.0 & & & 99.0 & 68.0 & 113.0 & 78.0 \\
\hline $\mathbf{N i}$ & & & & 41.0 & 40.0 & 37.0 & & & 26.0 & 26.0 & 45.0 & 35.0 \\
\hline Zn & & & & 94.0 & 83.0 & 77.0 & & & 78.0 & 56.0 & 100.0 & 83.0 \\
\hline $\mathbf{R b}$ & & & & 137.0 & 153.0 & 184.0 & & & 165.0 & 129.0 & 136.0 & 139.0 \\
\hline $\mathrm{Sr}$ & & & & 103.0 & 143.0 & 138.0 & & & 104.0 & 120.0 & 160.0 & 141.0 \\
\hline $\mathbf{Y}$ & & & & 41.0 & 20.0 & 26.0 & & & 22.0 & 22.0 & 23.0 & 27.0 \\
\hline $\mathbf{Z r}$ & & & & 134.0 & 154.0 & 226.0 & & & 149.0 & 177.0 & 135.0 & 225.0 \\
\hline $\mathrm{Nb}$ & & & & 17.0 & 22.0 & 20.0 & & & 15.0 & 16.0 & 14.0 & 18.0 \\
\hline Cs & & & & 14.1 & 6.6 & 9.7 & & & 14.0 & 8.8 & 7.0 & 7.4 \\
\hline $\mathbf{B a}$ & & & & 912.0 & 792.0 & 896.0 & & & 1048.0 & 718.0 & 826.0 & 703.0 \\
\hline La & & & & 49.1 & 42.6 & 42.9 & & & 46.6 & 34.1 & 52.8 & 50.1 \\
\hline $\mathrm{Ce}$ & & & & 93.6 & 85.3 & 84.9 & & & 91.4 & 73.1 & 94.3 & 96.0 \\
\hline Nd & & & & 43.0 & 30.0 & 35.0 & & & 36.0 & 24.0 & 38.0 & 39.0 \\
\hline Sm & & & & 7.56 & 5.96 & 5.94 & & & 6.29 & 4.88 & 6.46 & 6.97 \\
\hline Eu & & & & 1.54 & 1.20 & 1.32 & & & 1.31 & 1.14 & 1.32 & 1.43 \\
\hline $\mathbf{T b}$ & & & & 1.3 & 0.9 & 1.0 & & & 0.8 & 0.5 & 1.0 & 1.1 \\
\hline $\mathbf{Y b}$ & & & & 4.9 & 2.9 & 3.3 & & & 3.4 & 3.0 & 2.8 & 3.3 \\
\hline Lu & & & & 0.57 & 0.39 & 0.35 & & & 0.48 & 0.43 & 0.48 & 0.42 \\
\hline Hf & & & & 3.9 & 4.4 & 6.5 & & & 4.0 & 6.0 & 4.3 & 6.9 \\
\hline Ta & & & & 2.1 & 2.3 & 2.3 & & & 2.2 & 1.0 & 0.9 & 2.1 \\
\hline Th & & & & 11.6 & 14.1 & 14.6 & & & 11.9 & 11.7 & 15.3 & 15.5 \\
\hline $\mathbf{U}$ & & & & 3.2 & 3.0 & 2.3 & & & 3.0 & 1.5 & 1.6 & 3.0 \\
\hline
\end{tabular}

logical Survey, Prague (Bártek 1979). The location of the analyzed Kaplice Unit samples is shown in Table 3 and Fig. 1. Fifteen homogenized aliquots from the original sample set were analyzed by XRF and INA methods for minor and trace elements in Gematrix laboratory, Černošice, in 1991. The results are presented in Tables 1 and 2. Table 4 presents averages with standard deviations for three major compositional types of muscovite-biotite gneisses of the Kaplice Unit.

The average composition for 11 gneisses of the Variegated Unit (V-Unit in Table 4) is based on data by Bouška et al. (1985) and used for comparison with gneisses from the Kaplice Unit. The set for the Variegated Unit comprises 9 samples from the Pilát quarry near Soběslav (biotite paragneisses and two hornblende-biotite paragneisses), and two samples from environment of Český Krumlov, including a calc-silicate gneiss. This set was compared with two sets of paragneisses (major elements only), largely from the Monotonous Unit in the region between Tábor and České Budějovice, i.e., north of the Kaplice Unit. One of these sets (marked CS in Fig. 9) contains analyses compiled by Suk (1973); the other set (EM) includes paragneiss analyses from Explanations to individual $1: 25000$ map sheets. The comparison shows a limited compositional variation of the Moldanubian paragneisses in the respective areas (Vrána et al. 1993, Table 6 and Fig. 2 showing sample location for the additional two sets of paragneisses). 
Table 2. Chemical analyses of Ca-rich and Na-rich muscovite-biotite gneisses, Kaplice Unit.

\begin{tabular}{|c|c|c|c|c|c|c|c|c|c|c|c|c|c|c|c|}
\hline \multirow[b]{2}{*}{$\begin{array}{l}\text { Sample } \\
\text { No. }\end{array}$} & \multirow[b]{2}{*}{17} & \multicolumn{6}{|c|}{ Ca-rich gneisses } & \multicolumn{8}{|c|}{ Na-rich gneisses } \\
\hline & & 18 & 22 & 23 & $24 a$ & 27 & 28 & 9 & 11 & 13 & 14 & 15 & 19 & 21 & 25 \\
\hline $\mathrm{SiO}_{2}$ & 79.14 & 58.14 & 74.48 & 69.39 & 77.42 & 87.74 & 82.74 & 60.90 & 76.06 & 77.08 & 80.46 & 72.80 & 74.12 & 76.37 & 80.68 \\
\hline $\mathrm{TiO}_{2}^{2}$ & 0.45 & 0.98 & 0.58 & 0.76 & 0.50 & 0.30 & 0.43 & 0.86 & 0.43 & 0.55 & 0.49 & 0.47 & 0.52 & 0.45 & 0.42 \\
\hline $\mathrm{Al}_{2} \mathrm{O}_{3}$ & 9.73 & 17.92 & 12.03 & 13.48 & 10.87 & 5.24 & 7.14 & 18.57 & 11.02 & 11.37 & 9.66 & 12.30 & 12.52 & 12.05 & 9.91 \\
\hline $\mathrm{Fe}_{2}^{2} \mathrm{O}_{3}$ & 0.77 & 1.73 & 0.57 & 0.85 & 0.85 & 0.50 & 0.43 & 1.82 & 0.81 & 1.04 & 0.86 & 0.78 & 0.83 & 0.53 & 0.65 \\
\hline $\mathrm{FeO}^{3}$ & 1.83 & 4.55 & 2.20 & 3.03 & 1.65 & 0.53 & 1.90 & 3.89 & 1.56 & 1.15 & 1.57 & 3.30 & 2.00 & 1.73 & 1.28 \\
\hline MnO & 0.04 & 0.07 & 0.04 & 0.07 & 0.07 & 0.01 & 0.02 & 0.06 & 0.02 & 0.03 & 0.07 & 0.07 & 0.04 & 0.05 & 0.01 \\
\hline MgO & 0.96 & 3.23 & 1.18 & 2.55 & 0.83 & 0.38 & 1.37 & 2.67 & 0.94 & 0.86 & 0.74 & 1.79 & 1.04 & 0.80 & 0.78 \\
\hline $\mathrm{CaO}$ & 1.34 & 2.24 & 2.37 & 2.72 & 1.35 & 1.45 & 1.60 & 1.18 & 0.59 & 0.84 & 0.69 & 0.72 & 0.95 & 1.04 & 0.54 \\
\hline $\mathrm{Li}_{2} \mathrm{O}$ & 0.004 & 0.010 & 0.003 & 0.030 & 0.004 & 0.001 & 0.004 & 0.009 & 0.003 & 0.002 & n.d. & 0.060 & 0.003 & n.d. & 0.001 \\
\hline $\mathrm{Na}_{2} \mathrm{O}$ & 2.77 & 4.13 & 3.17 & 2.62 & 3.29 & 1.30 & 1.05 & 2.91 & 2.63 & 2.91 & 2.00 & 3.00 & 3.33 & 2.76 & 2.46 \\
\hline $\mathrm{K}_{2} \mathrm{O}$ & 1.12 & 3.72 & 1.42 & 2.24 & 1.65 & 0.87 & 1.16 & 3.62 & 2.20 & 2.26 & 1.70 & 2.28 & 2.38 & 2.52 & 1.64 \\
\hline $\mathrm{P}_{2} \mathrm{O}_{5}$ & 0.13 & 0.12 & 0.30 & 0.14 & 0.18 & 0.08 & 0.12 & 0.09 & 0.08 & 0.12 & 0.15 & 0.12 & 0.43 & 0.20 & 0.12 \\
\hline $\mathrm{CO}_{2}$ & 0.026 & 0.030 & 0.008 & 0.005 & 0.036 & 0.005 & 0.005 & 0.018 & 0.008 & 0.008 & 0.005 & 0.020 & 0.014 & n.d. & 0.006 \\
\hline $\mathrm{C}$ & - & - & - & - & - & 0.026 & - & n.d. & 0.010 & 0.030 & n.d. & 0.030 & n.d. & n.d. & 0.010 \\
\hline $\mathbf{F}$ & 0.04 & 0.11 & 0.04 & 0.05 & 0.04 & 0.02 & 0.04 & 0.09 & 0.04 & 0.04 & n.d. & 0.04 & 0.05 & n.d. & 0.03 \\
\hline Cl & 0.01 & 0.01 & 0.01 & 0.01 & 0.01 & 0.01 & 0.01 & 0.01 & 0.01 & 0.01 & n.d. & 0.01 & 0.01 & n.d. & 0.01 \\
\hline $\mathbf{S}$ & 0.005 & 0.010 & 0.010 & 0.005 & 0.020 & 0.005 & 0.005 & 0.010 & 0.010 & 0.005 & 0.005 & 0.010 & 0.010 & n.d. & 0.005 \\
\hline $\mathbf{H}_{2} \mathbf{O}^{+}$ & 0.94 & 2.17 & 0.82 & 1.30 & 0.72 & 0.52 & 1.13 & 2.59 & 1.23 & 0.97 & 0.89 & 1.87 & 1.16 & 0.83 & 1.01 \\
\hline $\mathbf{H}_{2}^{2} \mathbf{O}^{-}$ & 0.27 & 0.39 & 0.21 & 0.14 & 0.22 & 0.28 & 0.24 & 0.35 & 0.21 & 0.18 & 0.09 & 0.16 & 0.15 & 0.35 & 0.15 \\
\hline -F ekv. & 0.02 & 0.05 & 0.02 & 0.02 & 0.02 & - & 0.02 & 0.04 & 0.02 & 0.02 & - & 0.02 & 0.02 & - & - \\
\hline Total & 98.56 & 99.51 & 99.42 & 99.37 & 99.69 & 99.27 & 99.37 & 99.61 & 99.84 & 99.44 & 99.38 & 99.81 & 99.54 & 99.68 & 99.71 \\
\hline \multicolumn{16}{|c|}{ Minor and trace elements } \\
\hline Sc & 19.3 & 19.3 & 9.2 & 14.0 & 7.5 & & 5.7 & 18.9 & & & & & 8.0 & & \\
\hline $\mathbf{V}$ & 27 & 97 & 33 & 53 & 30 & & 29 & 33 & & & & & 34 & & \\
\hline $\mathrm{Cr}$ & 76 & 106 & 45 & 70 & 92 & & 42 & 90 & & & & & 40 & & \\
\hline $\mathrm{Ni}$ & 13 & 40 & 18 & 24 & 31 & & 23 & 40 & & & & & 17 & & \\
\hline $\mathrm{Zn}$ & 36 & 104 & 28 & 65 & 26 & & 38 & 28 & & & & & 30 & & \\
\hline $\mathbf{R b}$ & 53 & 150 & 67 & 77 & 52 & & 55 & 191 & & & & & 64 & & \\
\hline $\mathrm{Sr}$ & 153 & 227 & 245 & 207 & 216 & & 120 & 229 & & & & & 264 & & \\
\hline $\mathbf{Y}$ & 22 & 23 & 26 & 23 & 20 & & 17 & 26 & & & & & 21 & & \\
\hline $\mathbf{Z r}$ & 316 & 215 & 250 & 257 & 252 & & 341 & 250 & & & & & 256 & & \\
\hline $\mathbf{N b}$ & 17 & 17 & 17 & 15 & 14 & & 14 & 26 & & & & & 19 & & \\
\hline Cs & 3.5 & 13.3 & 4.1 & 5.1 & 4.5 & & 2.5 & 10.7 & & & & & 3.4 & & \\
\hline $\mathbf{B a}$ & 374 & 699 & 387 & 690 & 497 & & 261 & 530 & & & & & 824 & & \\
\hline La & 37.1 & 42.7 & 39.8 & 35.1 & 26.4 & & 21.4 & 50.6 & & & & & 34.5 & & \\
\hline $\mathrm{Ce}$ & 73.0 & 79.4 & 77.7 & 65.8 & 60.9 & & 40.9 & 99.7 & & & & & 70.0 & & \\
\hline Nd & 28 & 34 & 30 & 27 & 23 & & 21 & 39 & & & & & 24 & & \\
\hline Sm & 5.24 & 6.30 & 5.51 & 4.98 & 3.84 & & 3.48 & $7.1 \mathrm{C}$ & & & & & 4.57 & & \\
\hline Eu & 1.09 & 1.52 & 1.97 & 1.27 & 0.93 & & 0.66 & 1.42 & & & & & 1.02 & & \\
\hline $\mathbf{T b}$ & 1.0 & 1.0 & 0.8 & 1.0 & 0.5 & & 0.6 & 1.1 & & & & & 0.5 & & \\
\hline $\mathbf{Y b}$ & 3.2 & 3.3 & 2.3 & 2.9 & 3.4 & & 2.4 & 3.6 & & & & & 2.9 & & \\
\hline Lu & 0.21 & 0.64 & 0.28 & 0.41 & 0.38 & & 0.22 & 0.45 & & & & & 0.32 & & \\
\hline Hf & 8.0 & 7.2 & 6.6 & 8.8 & 7.6 & & 9.0 & 6.3 & & & & & 6.9 & & \\
\hline Ta & 6.9 & 2.2 & 4.6 & 3.6 & 2.8 & & 4.1 & 2.2 & & & & & 4.4 & & \\
\hline Th & 11.9 & 16.4 & 10.8 & 11.5 & 9.9 & & 8.0 & 14.8 & & & & & 11.6 & & \\
\hline $\mathbf{U}$ & 3.3 & 1.9 & 3.1 & $<0.8$ & $<0.8$ & & 0.9 & 3.2 & & & & & $<0.8$ & & \\
\hline
\end{tabular}

Bártek (1979) presented numerous microprobe analyses of the rock forming minerals used for estimates of metamorphic PT-conditions. New microprobe analyses are presented for calc-silicate gneisses and some other samples. Mineral compositions were analyzed by Z. Kotrba on ARL-EMX and CamScan-Link eXL microprobes in the Czech Geological Survey, Prague. An accelerating voltage of $15 \mathrm{kV}$, a beam current of $3 \mathrm{nA}$ and a counting time of 80 seconds were used. Natural minerals were used as standards and the ZAF correction program was employed.

\section{Geological setting of the Kaplice Unit}

In terms of its structural position, the Kaplice Unit is the lowermost metasedimentary member of the polycomponent crustal stack of southern Bohemia in the context of D3 structures. The unit, comprising muscovite-biotite paragneisses, with quartzite and calc-silicate gneiss intercalations, forms northwestern roof of the Variscan Moldanubian Batholith (Fig. 1). The unit trending NE-SW, $55 \mathrm{~km}$ long and 8 to $10 \mathrm{~km}$ wide, is at the southeastern border in a continuous intrusive contact with Eisgarn 
$\mathrm{Ta} \mathrm{b}$ le 3 . Location of muscovite-biotite gneiss samples from the Kaplice Unit.

\begin{tabular}{|c|c|c|}
\hline Sample No. & Map sheet $1: 25000$ & Sampling site \\
\hline 1 & 32-241 Velešín & $600 \mathrm{~m}$ west-southwest of Kladiny \\
\hline 2 & 32-241 Velešín & $500 \mathrm{~m}$ west of Zubčice \\
\hline 3 & 32-241 Velešín & $750 \mathrm{~m}$ northwest of Kladiny \\
\hline 4 & 32-243 Kaplice & $3.4 \mathrm{~km}$ south of Jistebník \\
\hline 5 & 32-243 Kaplice & $1.3 \mathrm{~km}$ south of Jistebník \\
\hline 6 & 32-243 Kaplice & $500 \mathrm{~m}$ south of Jistebník \\
\hline 7 & 32-243 Kaplice & 640 m south-southwest of Omlenička \\
\hline 8 & 32-243 Kaplice & southern edge of Hněvanov village \\
\hline 9 & 32-234 Světlík & $1.2 \mathrm{~km}$ southeast of Slubice \\
\hline 10 & 32-421 Rožmberk n. Vlt. & 650 m west of Rožmberk n. Vlt. \\
\hline 11 & 32-224 Borovany & southern edge of Pašínovice village \\
\hline 13 & 32-224 Borovany & southern edge of Pašínovice village \\
\hline 14 & 32-241 Velešín & $500 \mathrm{~m}$ west of Zubčice \\
\hline 15 & 32-241 Velešín & $750 \mathrm{~m}$ southwest of Kladiny \\
\hline 16 & 32-243 Kaplice & $750 \mathrm{~m}$ southwest of Michnice \\
\hline 17 & 32-243 Kaplice & $3.4 \mathrm{~km}$ south of Jistebník \\
\hline 18 & 32-243 Kaplice & $1.3 \mathrm{~km}$ south of Jistebník \\
\hline 19 & 32-243 Kaplice & $500 \mathrm{~m}$ south of Jistebník \\
\hline 20 & 32-243 Kaplice & SE end of ridge south of Rožmitál na Šumavě \\
\hline 21 & 32-243 Kaplice & top of Chudějovský vrch hill \\
\hline 22 & 32-234 Světlík & $1.2 \mathrm{~km}$ southeast of Slubice \\
\hline 23 & 32-421 Rožmberk n. Vlt. & 650 m west-southwest of Rožmberk n. Vlt. \\
\hline 24 & 32-421 Rožmberk n. Vlt. & 1.7 km south-southwest of Rožmberk n. Vlt. \\
\hline $24 a$ & 32-412 Vyšší Brod & $300 \mathrm{~m}$ south of Malšín \\
\hline 25 & $32-224$ Borovany & $500 \mathrm{~m}$ southeast of Stradov \\
\hline 26 & 32-242 Trhové Sviny & $800 \mathrm{~m}$ southwest of Polžov \\
\hline 27 & 32-242 Trhové Sviny & $1.3 \mathrm{~km}$ southeast of Todně \\
\hline 28 & 32-421 Rožmberk n. Vlt. & $1.2 \mathrm{~km}$ south-southwest of Rožmberk n. Vlt. \\
\hline
\end{tabular}

Ta ble 4. Major, minor, and trace elements in three main compositional groups of gneisses of the Kaplice Unit and in gneisses of the Variegated Unit.

\begin{tabular}{|c|c|c|c|c|c|c|c|c|c|c|c|c|c|c|c|c|c|c|}
\hline \multicolumn{9}{|c|}{ Major elements } & \multicolumn{10}{|c|}{ Minor and trace elements } \\
\hline & \multicolumn{2}{|c|}{$\begin{array}{c}\text { High-K } \\
\text { (n 12) }\end{array}$} & \multicolumn{2}{|c|}{$\begin{array}{c}\text { High-Ca } \\
\text { (n 7) }\end{array}$} & \multicolumn{2}{|c|}{$\begin{array}{c}\text { High-Na } \\
\text { (n 7) }\end{array}$} & \multicolumn{2}{|c|}{$\begin{array}{l}\text { V-Unit } \\
\text { (n 11) }\end{array}$} & & \multirow[t]{2}{*}{$\begin{array}{c}\text { High-K } \\
\text { (n 7) }\end{array}$} & \multirow[t]{2}{*}{$\begin{array}{l}\text { High-Ca } \\
\text { (n 6) }\end{array}$} & \multirow[t]{2}{*}{$\begin{array}{c}\text { High-Na } \\
\text { (n 2) }\end{array}$} & \multirow[t]{2}{*}{$\begin{array}{l}\text { V-Unit } \\
\text { (n 11) }\end{array}$} & & \multirow[t]{2}{*}{$\begin{array}{c}\text { High-K } \\
\text { (n 7) }\end{array}$} & \multirow[t]{2}{*}{$\begin{array}{c}\text { High-Ca } \\
\text { (n 6) }\end{array}$} & \multirow[t]{2}{*}{$\begin{array}{l}\text { High-Na } \\
\text { (n 2) }\end{array}$} & \multirow[t]{2}{*}{$\begin{aligned} \text { a } & \text { V-Unit } \\
& \text { (n 11) }\end{aligned}$} \\
\hline & $\mathrm{x}$ & $\mathrm{s}$ & $\mathrm{x}$ & $\mathrm{s}$ & $\mathrm{x}$ & $\mathrm{s}$ & $\mathrm{x}$ & $\mathrm{s}$ & & & & & & & & & & \\
\hline $\mathrm{SiO}_{2}$ & 61.64 & 4.30 & 75.58 & 9.70 & 77.08 & 3.00 & 60.85 & 4.10 & Sc & 18.4 & 10.3 & 13.5 & 18.5 & Sm & 6.30 & 4.90 & 5.90 & 7.10 \\
\hline $\mathrm{TiO}_{2}$ & 0.80 & 0.10 & 0.57 & 0.23 & 0.48 & 0.05 & 0.74 & 0.16 & $\mathbf{V}$ & 83.0 & 45.0 & 57.0 & - & Eu & 1.32 & 1.24 & 1.22 & 1.36 \\
\hline $\mathrm{Al}_{2} \mathrm{O}_{3}$ & 18.06 & 2.10 & 10.92 & 4.20 & 11.26 & 1.10 & 17.47 & 1.70 & $\mathrm{Cr}$ & 86.0 & 72.0 & 65.0 & 88.0 & $\mathbf{T b}$ & 0.90 & 0.80 & 0.80 & 0.97 \\
\hline $\mathrm{Fe}_{2} \mathrm{O}_{3}$ & 1.83 & 0.76 & 0.81 & 0.44 & 0.79 & 0.16 & 1.00 & 0.24 & $\mathbf{N i}$ & 36.0 & 25.0 & 29.0 & 19.0 & $\mathbf{Y b}$ & 3.40 & 2.80 & 3.30 & 3.10 \\
\hline $\mathrm{FeO}$ & 4.24 & 0.61 & 2.24 & 1.30 & 1.80 & 0.72 & 4.76 & 0.77 & Zn & 82.0 & 50.0 & 58.0 & 108.0 & Lu & 0.45 & 0.36 & 0.38 & 0.42 \\
\hline $\mathrm{MnO}$ & 0.075 & 0.030 & 0.045 & 0.020 & 0.040 & 0.020 & 0.090 & 0.040 & $\mathbf{R b}$ & 149.0 & 77.0 & 130.0 & 108.0 & Hf & 5.10 & 7.90 & 6.60 & 5.40 \\
\hline MgO & 2.60 & 0.52 & 1.50 & 1.00 & 0.99 & 0.37 & 2.85 & 0.41 & Sr & 130.0 & $0 \quad 195.0$ & 247.0 & 324.0 & $\mathbf{T a}$ & 1.80 & 4.00 & 3.30 & 1.20 \\
\hline $\mathrm{CaO}$ & 0.68 & 0.21 & 1.87 & 0.56 & 0.77 & 0.19 & 2.83 & 1.80 & $\mathbf{Y}$ & 26.0 & 22.0 & 23.0 & 26.0 & Th & 13.50 & 11.40 & 13.20 & 13.40 \\
\hline $\mathrm{Na}_{2} \mathrm{O}$ & 1.57 & 0.29 & 2.62 & 1.10 & 2.73 & 0.42 & 2.95 & 1.10 & $\mathbf{Z r}$ & 171.0 & 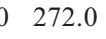 & 227.0 & - & $\mathbf{U}$ & 2.50 & 1.70 & 1.90 & 3.20 \\
\hline $\mathbf{K}_{2} \mathbf{O}$ & 4.45 & 0.71 & 1.74 & 0.98 & 2.14 & 0.34 & 3.22 & 1.00 & Nb & 17.0 & 16.0 & 22.0 & - & & & & & \\
\hline $\mathrm{P}_{2} \mathrm{O}_{5}$ & 0.16 & 0.04 & 0.15 & 0.07 & 0.17 & 0.12 & 0.20 & 0.06 & Cs & 9.6 & 5.5 & 7.0 & 6.3 & & & & & \\
\hline $\mathrm{CO}_{2}$ & 0.03 & 0.04 & 0.02 & 0.01 & 0.01 & 0.01 & 0.55 & 0.48 & Ba & 842.0 & 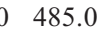 & 677.0 & 626.0 & & & & & \\
\hline $\mathbf{F}$ & 0.07 & 0.02 & 0.05 & 0.03 & 0.04 & 0.01 & - & - & La & 45.6 & 33.8 & 42.6 & 37.6 & & & & & \\
\hline $\mathbf{S}$ & 0.01 & 0.00 & 0.01 & 0.01 & 0.01 & 0.00 & - & - & Ca & 88.4 & 66.3 & 85.0 & 90.2 & & & & & \\
\hline $\mathrm{H}_{2} \mathrm{O}^{+}$ & 3.05 & 0.49 & 1.09 & 0.54 & 1.14 & 0.35 & 1.78 & 0.75 & Nd & 35.0 & 27.0 & 31.0 & 41.5 & & & & & \\
\hline
\end{tabular}

Localities for the samples are shown in Fig.1. Listing of samples included in respective compositional groups:

"High-K" gneisses: 1, 2, 3, 4, 5, 6, 7, 8, 10, 16, 20, 24

"High-Ca" gneisses: 17, 18, 22, 23, 24a, 27, 28

"High-Na" gneisses: 11, 13, 14, 15, 19, 21, 25

"V-Unit" - average composition of gneisses of the Variegated Unit (Vrána et al. 1993, based on data by Bouška et al. 1985)

muscovite-biotite granite, which is a marginal, relatively late member of the Moldanubian Batholith ( 330-320 Ma, Gerdes et al. 2002). The Kaplice Unit is split in two parts by the N-S trending Kaplice-Rödl fault zone with a major sinistral component (Fig. 1). At the northwest, the unit is in contact with sillimanite-biotite paragneiss of the Monotonous Unit. This contact is represented east of the Kaplice fault zone by examples of tectonometamorphic transition envolving sillimanite-biotite gneiss modified by newly imprinted S3 shear foliation and fabric reorientation, resulting in gradual transformation of the parent gneisses to muscovite-biotite gneiss of the Kaplice Unit. The regional pattern of this transition is complicated by late, semi-brittle strike-slip faults, e.g. the 


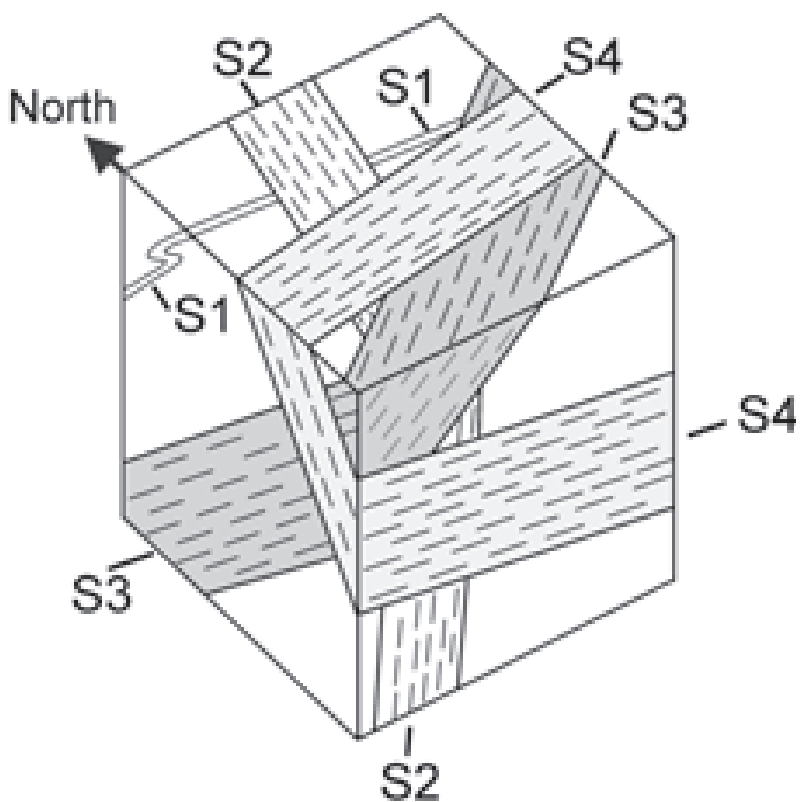

Fig. 2. Sequence of the superimposed shear-deformation structures in the Kaplice Unit. Relative age: $\mathrm{S} 1>\mathrm{S} 2>\mathrm{S} 3>\mathrm{S} 4$. Estimated preservation of structural generations in the Kaplice Unit: $\mathrm{S} 1<1 \%$, S2 $<3 \%$, $\mathrm{S} 3>90 \%, \mathrm{~S} 4<5 \%$. S3 domain is indicated by medium grey colour, S4 domain by light grey colour.
Strážkovice fault (Vrána 1979) and some late transversal faults. In the segment west of the Kaplice fault zone, the contact between the Kaplice Unit and the structurally overlying sillimanite-biotite gneiss of the Monotonous Unit coincides with a ca. $100 \mathrm{~m}$ wide zone of late, semibrittle mylonites, indicating a late relative displacement of the two units.

At the SW, the Kaplice Unit is terminated on late, NWSE trending faults of the Šumava (Bohemian Forest) mountain chain that brought to the surface relatively deeper crustal domains. The last fault-bound slices of the Kaplice Unit at its southwestern termination are tectonically inserted in Weinsberg biotite granite (Pelc 1990). At the NE, the Upper Cretaceous sediments of the Třeboň Basin overlie the Kaplice Unit and obscure its possible continuation toward the NE.

\section{Structural relations}

Structural relations are documented on mesoscopic to thin section scale by field and microscopic work associated with the regional mapping (Fig. 1). Alternation of massive ("meta-greywacke") gneisses with mica-rich, strong-
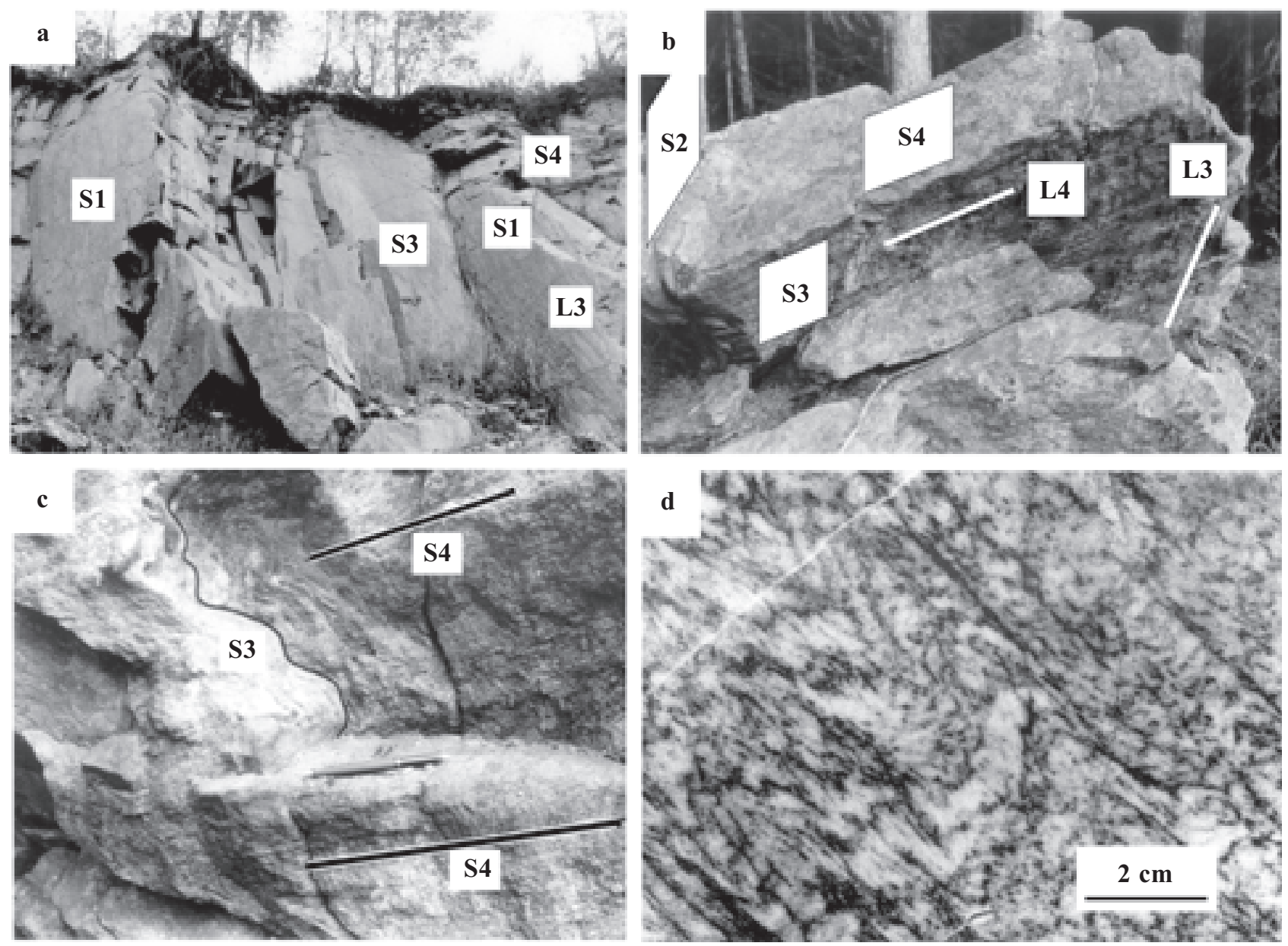

Fig. 3. Structural relations. a - Foliation S1 in part overprinted by S3 foliation, S4 at top right is a late fracture cleavage; Strážkovice quarry, sillimanite-biotite gneiss $1 \mathrm{~km}$ north of the Kaplice Unit; view toward the S; b - relations of S3 and S4 shear foliation to S2 planar structure defined by quartzitic and mica-rich bands in the Kaplice Unit, view toward the N; Horní Světlá 5 km northeast of Frymburk; c - deformation of S3 foliation by S4 crenulation cleavage in mica-rich gneiss of the Kaplice Unit, view toward the SW; d - S3 planar fabric deformed by S4 crenulation in biotite quartzite, borehole at Todeňská hora hill, $5.5 \mathrm{~km}$ west of Trhové Sviny. 

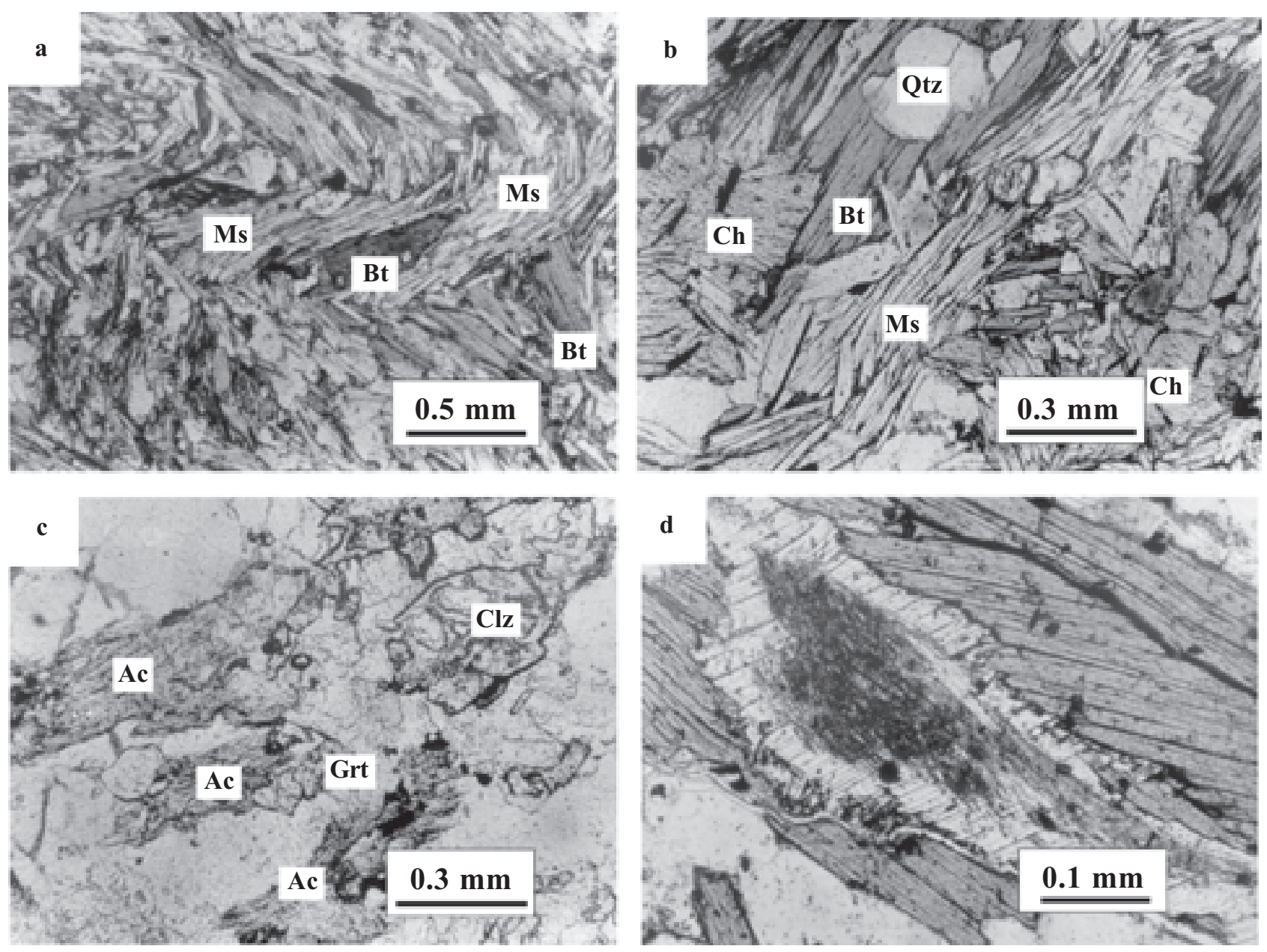

Fig. 4. a - F4 crenulation folds deform S3 schistosity in mica-rich paragneiss of the Kaplice Unit, Ms muscovite, Bt biotite; b - chlorite (Ch) aggregates in S4 schistosity defined by muscovite (Ms) and biotite (Bt), mica-rich paragneiss of the Kaplice Unit, east of Něchov village; $\mathrm{c}$ - newly formed actinolite (Ac), clinozoisite (Clz) and garnet (Grt) in retrogressed calc-silicate gneiss, Zubčice quarry; $\mathrm{d}$ - fibrolitic sillimanite aggregate mantled by muscovite against biotite. Photomicrographs in transmitted light, single polarizer.

ly foliated gneisses (Čech et al. 1960) has been recorded early as a typical lithological feature of the unit. There is a strong evidence that this lithological layering and planar structures (S3) correspond to superimposed shearing, re-foliation, and transposition of local lithological domains. The evidence includes examples of mesoscopic and outcrop-size relics (localized low-strain domains) preserving older structures (Fig. 3). Occasionally, trails of fine opaque particles in plagioclase and biotite, making an angle of up to $40^{\circ}$ with S3 mesoscopic foliation clearly exclude the possibility of the dominant foliation corresponding to bedding. A sequence of structures designated conventionally as D1 to D4 (Vrána 1979, 1992) and shown schematically in Fig. 2 is based on observations and measurements of a large number of outcrops. Simple criteria of field determination of the relative age of planar structures, as indicated by intersection relation and structural superposition, show that the individual sets of planar and linear structures exhibit coherent and regular time relations. Corresponding structural generations and patterns are also documented in paragneisses of the Monotonous Unit to the north of the Kaplice Unit. The early structures D1 and D2, extensively overprinted by
D3 shear foliation, occur northwest of Trhové Sviny (Vrána 1979). However, the late crenulation cleavage D4 appears to be confined to the mica-rich gneisses of the Kaplice Unit. In the Kaplice Unit the pre-D3 structural relics are only preserved on the scale of metres. The regionally prevalent, monoclinal S3 foliation trending NE-SW and dipping to the NW is an important reference structure, as is the case over much of the south-central Bohemian part of the Moldanubian Zone. The D3 deformation event is responsible for a strong structural transposition on regional scale, resulting in parallelism of lithological layering.

The kinematic characteristics for structures D1 and D2 are absent. D3 has been characterized as an extension deformation (Lobkowicz et al. 1996), with top-to-NW transport. The D4 crenulation cleavage with S4 dipping to the south, i.e. opposit to S3, carries evidence of an extension deformation with top-to-south sense of movement (Fig. 3). Quartz segregation lenses with large crystals of andalusite and rare cordierite are deformed by D4. Gneisses showing D4 crenulation exhibit recrystallization of the muscovite-biotite quartz mosaic along the axial planar cleavage (Fig. 4), however, chlorite often appears as an additional phase in these domains (Fig. 4). 


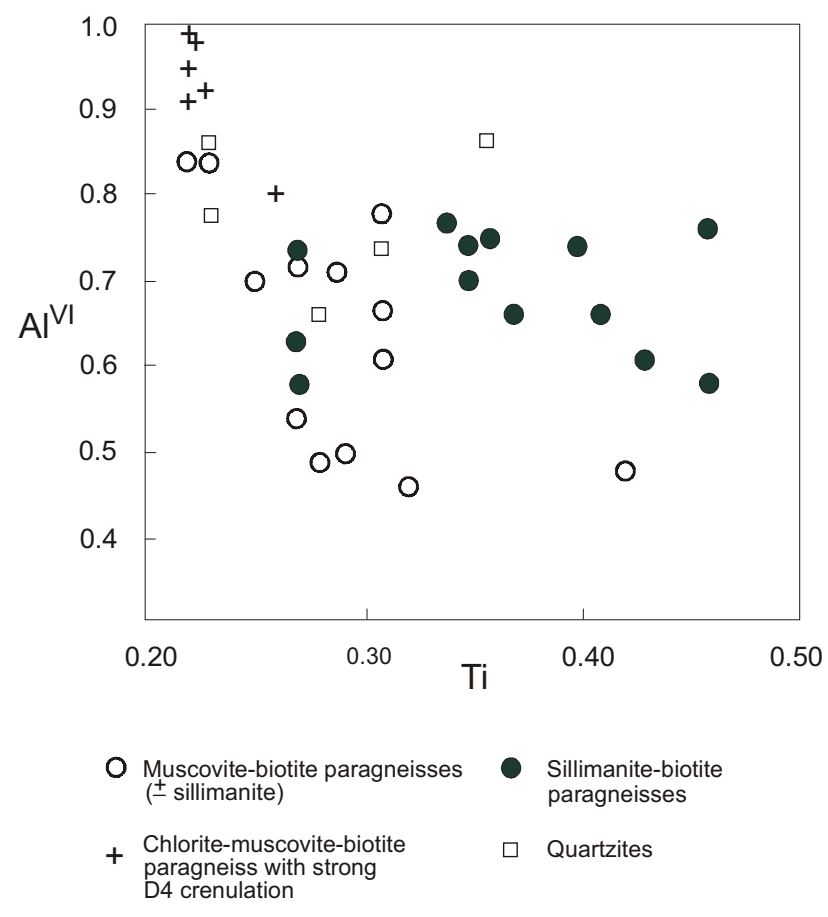

Fig. 5. Plot of $\mathrm{Al}^{\mathrm{VI}}$ vs Ti per formula unit of biotite in sillimanite-biotite paragenisses (Monotonous Unit adjacent to the Kaplice Unit) and in muscovite-biotite gneisses (Kaplice Unit) based on calculation of biotite analyses to $22(\mathrm{O})$.

The airborne regional magnetometry mapping resulted in recognition of a large number of several $\mathrm{km}$ long linear anomalies running NE-SW, parallel to the regional trend of the Kaplice Unit (Šalanský 1967). Detailed surface magnetometry profiles proved (Šalanský et al. 1983) that at least some magnetized zones are dipping to the SSE, parallel to the south-dipping crenulation cleavage S4. This indicates that much of superimposed oxidation postdates S3 transposition foliation and lithological layering that dip to the NW. The oxidation is conserved by amphibolite-facies mineral assemblage but magnetite production in a form of finely dispersed particles continued during crystallization of chlorite+ilmenite in S4 crenulation cleavage. Magnetite crystals up to $0.5 \mathrm{~mm}$ across, dark grey-brown biotite (parallel Y, Z) rather than the ordinary bright brown bi-

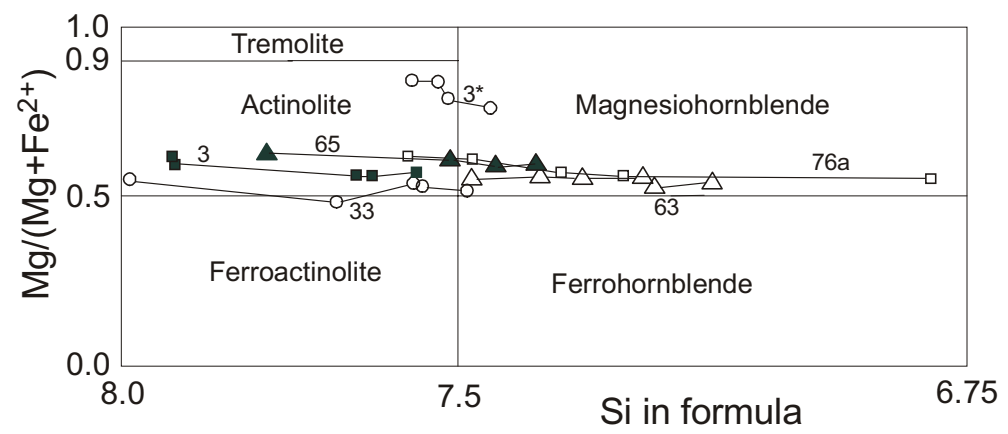

Fig. 6. Composition of actinolite and low-Al magnesiohornblende in calc-silicate gneisses and quartzites in the Kaplice Unit. Symbols indicate the range of amphibole composition in individual samples.
Table 5. Microprobe analyses of minerals in chlorite-muscovitebiotite paragneiss showing a strong D4 crenulation.

\begin{tabular}{|c|c|c|c|c|}
\hline Mineral & Biotite & Muscovit & Chlorite & Ilmenite \\
\hline $\mathrm{SiO}_{2}$ & 36.76 & 48.81 & 25.51 & 0.06 \\
\hline $\mathrm{TiO}_{2}^{2}$ & 2.00 & 0.49 & 0.14 & 55.25 \\
\hline $\mathrm{Al}_{2} \mathrm{O}_{3}$ & 20.16 & 37.46 & 24.05 & 0.08 \\
\hline $\mathrm{FeO}^{2}$ & 20.09 & 1.21 & 26.23 & 41.90 \\
\hline MnO & 0.10 & 0.00 & 0.27 & 2.26 \\
\hline MgO & 9.33 & 0.73 & 13.32 & 0.06 \\
\hline $\mathrm{CaO}$ & 0.00 & 0.00 & 0.00 & 0.00 \\
\hline $\mathrm{Na}_{2} \mathrm{O}$ & 0.06 & 0.56 & 0.00 & 0.00 \\
\hline $\mathbf{K}_{2} \mathbf{O}$ & 8.47 & 8.94 & 0.02 & 0.00 \\
\hline Total & 96.95 & 98.20 & 89.53 & 99.61 \\
\hline \multicolumn{5}{|c|}{ Number of ions } \\
\hline \multicolumn{3}{|c|}{$24(\mathrm{O}+\mathrm{OH})$} & $18(\mathrm{O}+\mathrm{OH})$ & 4 cats \\
\hline Si & 5.449 & 6.210 & 2.630 & 0.003 \\
\hline $\mathbf{A} \mathbf{I}^{\mathrm{IV}}$ & 2.551 & 1.790 & 1.370 & \\
\hline $\mathbf{A l}^{\mathrm{VI}}$ & 0.971 & 3.826 & 1.553 & 0.005 \\
\hline $\mathbf{T i}$ & 0.223 & 0.046 & 0.010 & 2.111 \\
\hline $\mathrm{Fe}^{3+}$ & - & - & - & - \\
\hline $\mathrm{Fe}^{2+}$ & 2.490 & 0.129 & 2.262 & 1.780 \\
\hline Mn & 0.012 & - & 0.023 & 0.097 \\
\hline Mg & 2.062 & 0.139 & 2.047 & 0.005 \\
\hline $\mathbf{N a}$ & 0.017 & 0.138 & - & - \\
\hline $\mathbf{K}$ & 1.602 & 1.451 & 0.003 & - \\
\hline
\end{tabular}

otite and grey-green or blue-green tourmaline rather than the ordinary light brown type are typical in several samples of oxidized gneisses with predominant S3 fabric.

\section{Petrology}

\section{Paragneisses}

Muscovite-biotite gneisses have mainly the following mineral assemblages:

muscovite+biotite+ + plagioclase + quartz

muscovite + biotite + sillimanite + plagioclase + quartz \pm garnet chlorite + muscovite + biotite + plagioclase + quartz muscovite + biotite + staurolite + plagioclase + quartz \pm andalusite, sillimanite

The last mineral assemblage, in some cases with cordierite, represents sites near contact with Eisgarn granite.

Biotite in muscovite-biotite gneisses contains mainly 0.28 to $0.32 \mathrm{Ti}$ ions per formula unit (Fig. 5, Table 5). Biotite in biotite or sillimanite-biotite paragneisses of the Monotonous Unit (muscovitefree, or carrying a minor, late low-T muscovite), structurally overlying the Kaplice Unit, and from localities in the northern part of the Kaplice Unit near to the Monotonous Unit, contains 0.33 to $0.46 \mathrm{Ti}$ ions per formula unit. Muscovite has only a rather low phengitic substitution of 3 to 9 mol. \% and 13 to 16 mol.\% paragonite (Bártek 1979).

Sillimanite disappears concurrently with progressive development of S3 shear foliation and with proliferation of muscovite. In gneisses with D4 crenulation, fibrolitic sillimanite is 
Ta b l e 6. Composition of minerals in calc-silicate gneisses.

\begin{tabular}{|c|c|c|c|c|c|c|c|c|c|}
\hline $\begin{array}{l}\text { Sample } \\
\text { Mineral }\end{array}$ & \begin{tabular}{|l|}
$3 / 4^{*}$ \\
Act
\end{tabular} & $\begin{array}{c}3 \\
\text { Act }\end{array}$ & $\begin{array}{c}33 \\
\text { Act }\end{array}$ & $\begin{array}{c}65 \\
\text { Mg-Hbl }\end{array}$ & $\begin{array}{c}76 a \\
\text { Mg-Hbl }\end{array}$ & $\begin{array}{c}33 \\
\text { Grt }\end{array}$ & $\begin{array}{c}33 \\
\text { Grt }\end{array}$ & $\begin{array}{c}33 \\
\text { Czo }\end{array}$ & $\begin{array}{l}33 \\
\text { An }\end{array}$ \\
\hline $\mathrm{SiO}_{2}$ & 52.09 & 52.11 & 51.50 & 50.21 & 49.94 & 38.81 & 37.72 & 39.08 & 44.52 \\
\hline $\mathrm{TiO}_{2}^{2}$ & 0.07 & 0.16 & 0.06 & 0.14 & 0.46 & 0.10 & 0.32 & 0.00 & 0.00 \\
\hline $\mathrm{Al}_{2} \mathrm{O}_{3}$ & 3.29 & 3.39 & 3.59 & 5.84 & 5.77 & 21.73 & 22.39 & 29.57 & 34.45 \\
\hline $\mathrm{FeO}^{\circ}$ & 12.62 & 16.79 & 18.54 & 16.01 & 16.61 & 21.21 & 17.46 & $2.95 *$ & 0.05 \\
\hline MnO & 0.85 & 0.86 & 0.71 & 0.83 & 0.81 & 7.40 & 13.04 & 0.17 & 0.00 \\
\hline MgO & 15.94 & 12.30 & 11.25 & 12.14 & 12.37 & 1.37 & 0.64 & 0.02 & 0.00 \\
\hline $\mathrm{CaO}$ & 12.88 & 11.78 & 12.29 & 11.72 & 11.25 & 9.66 & 8.10 & 23.31 & 18.60 \\
\hline $\mathrm{Na}_{2} \mathrm{O}$ & 0.14 & 0.23 & 0.16 & 0.33 & 0.25 & 0.01 & 0.00 & 0.00 & 0.73 \\
\hline $\mathbf{K}_{2} \mathbf{O}$ & 0.06 & 0.10 & 0.11 & 0.35 & 0.21 & 0.00 & 0.00 & 0.02 & 0.02 \\
\hline Total & 97.95 & 97.62 & 98.21 & 97.57 & 97.67 & 100.30 & 99.67 & 95.12 & 98.37 \\
\hline $\begin{array}{l}\begin{array}{l}\text { Number } \\
\text { of ions }\end{array} \\
\end{array}$ & \multicolumn{5}{|c|}{$24(\mathrm{O}+\mathrm{OH})$} & 16 cats & 16 cats & 8 cats & $32(0)$ \\
\hline $\mathbf{S i}$ & 7.530 & 7.660 & 7.607 & 7.391 & 7.353 & 6.000 & 5.862 & 3.080 & 8.342 \\
\hline $\mathbf{A l}^{\mathrm{IV}}$ & 0.470 & 0.340 & 0.393 & 0.609 & 0.647 & 0.000 & 0.138 & 0.000 & \\
\hline $\mathbf{A l}^{\mathrm{VI}}$ & 0.090 & 0.247 & 0.232 & 0.404 & 0.354 & 3.959 & 3.963 & 2.746 & 7.615 \\
\hline $\mathrm{Fe}^{3+}$ & - & - & - & - & - & 0.029 & 0.000 & 0.097 & 0.008 \\
\hline $\mathbf{T i}$ & 0.008 & 0.017 & 0.007 & 0.015 & 0.050 & 0.011 & 0.037 & 0.000 & - \\
\hline Mg & 3.435 & 2.695 & 2.477 & 2.664 & 2.715 & 0.316 & 0.148 & 0.000 & 0.000 \\
\hline $\mathrm{Fe}^{2+}$ & 1.525 & 2.064 & 2.290 & 1.971 & 2.045 & 2.713 & 2.269 & 0.097 & 0.000 \\
\hline Mn & 0.104 & 0.107 & 0.088 & 0.104 & 0.101 & 0.969 & 1.716 & 0.004 & 0.000 \\
\hline $\mathrm{Ca}$ & 1.995 & 1.855 & 1.945 & 1.849 & 1.774 & 1.600 & 1.349 & 1.968 & 3.738 \\
\hline $\mathrm{Na}$ & 0.039 & 0.052 & 0.046 & 0.094 & 0.071 & - & - & 0.000 & 0.266 \\
\hline $\mathbf{K}$ & 0.011 & 0.019 & 0.020 & 0.065 & 0.039 & - & - & 0.000 & 0.005 \\
\hline Alm & & & & & & 48.42 & 41.25 & & \\
\hline Sps & & & & & & 17.29 & 31.20 & & \\
\hline Prp & & & & & & 5.63 & 2.70 & & \\
\hline Grs & & & & & & 27.57 & 23.84 & & \\
\hline Ti-Grs & & & & & & 0.31 & 1.02 & & \\
\hline Adr & & & & & & 0.78 & - & & \\
\hline
\end{tabular}

Explanation:

Act - actinolite

$\mathrm{Mg}-\mathrm{Hbl}$ - magnesiohornblende

Grt - garnet

Czo - clinozoisite

An - anorthite

Location of the analyzed samples is shown in Fig. 1

absent or it occurs in relict aggregates armoured by muscovite (Fig. 4).

Garnet is distinguished from garnets in higher-grade gneisses in the Moldanubian Zone by its relative rarity, abundance of dusty inclusions and irregular shapes. Seven garnet analyses in gneisses of the Kaplice Unit (Bártek 1979) show (mol.\%) 2.6-8.9 Grs, 7.0-10.0 Prp, 7.4-28.0 Sps (typically 16-25 Sps), and 61.476.6 Alm. Minor garnet in retrogressed calc-silicate gneisses with newly formed actinolite also contains significant spessartine (Table 6). Since gneisses have normal, low$\mathrm{MnO}$ abundances and garnet contents are minor, it is probable that the increased Mn stabilizes garnet under conditions that fall at a margin of garnet stability field.

In the contact zone of Eisgarn granite, 0.1 to $1.5 \mathrm{~km}$ wide, andalusite, cordierite and coarse sillimanite III appear as additional phases (Waldmann 1930, Čech et al. 1960) and others. Pletánek - Suk (1976) delimited migmatization and contact metamorphism zones in the area southwest of Kaplice.

\section{Calc-silicate gneisses}

Quartzites free of Ca-rich minerals form several horizons up to $100 \mathrm{~m}$

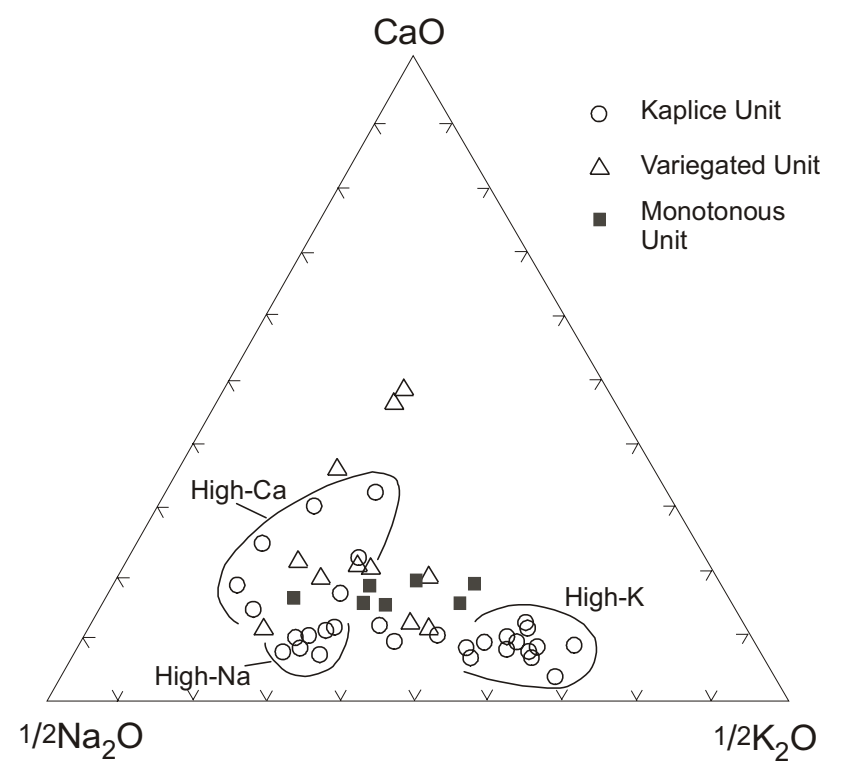

Fig. 7. A plot of muscovite-biotite gneisses of the Kaplice Unit and biotite gneisses of the Variegated and Monotonous Units in $\mathrm{CaO}-$ $-1 / 2 \mathrm{Na}_{2} \mathrm{O}-1 / 2 \mathrm{~K}_{2} \mathrm{O}$ (mol. \%) diagram. The values were calculated as katanorm numbers and allow comparison of rocks in terms of the relative normative content of $\mathrm{An}, \mathrm{Ab}$, and Or. thick, mainly in the NE part of the unit. Calc-silicate gneisses accompany these quartzites or occur independently as scattered lenses and pods. The sample set includes variation from diopside-rich samples nearly free of retrogresssion to samples showing a moderate to complete reaction of diopside to actinolite or low-Al magnesiohornblede. Composition of retrogression amphiboles is presented in Table 6 and Fig. 6. Incipient retrogression results in actinolite aggregates around diopside but many samples show a complete replacement of diopside by actinolite. In contrast to this, reaction of calcic plagioclase to clinozoisite and minor $\mathrm{Ca}$-rich garnet is often rather limited. The structural relations indicate the following reactions:

5 diopside $+\mathrm{H}_{2} \mathrm{O} \rightarrow$ actinolite $+2 \mathrm{SiO}_{2}+3 \mathrm{CaO}$

3 anorthite $+\mathrm{H}_{2} \mathrm{O}+\mathrm{CaO} \rightarrow$ clinozoisite

\section{Geochemistry of paragneisses}

Twenty seven whole-rock analyses of gneisses from the Kaplice Unit are used for compositional characterisation. 


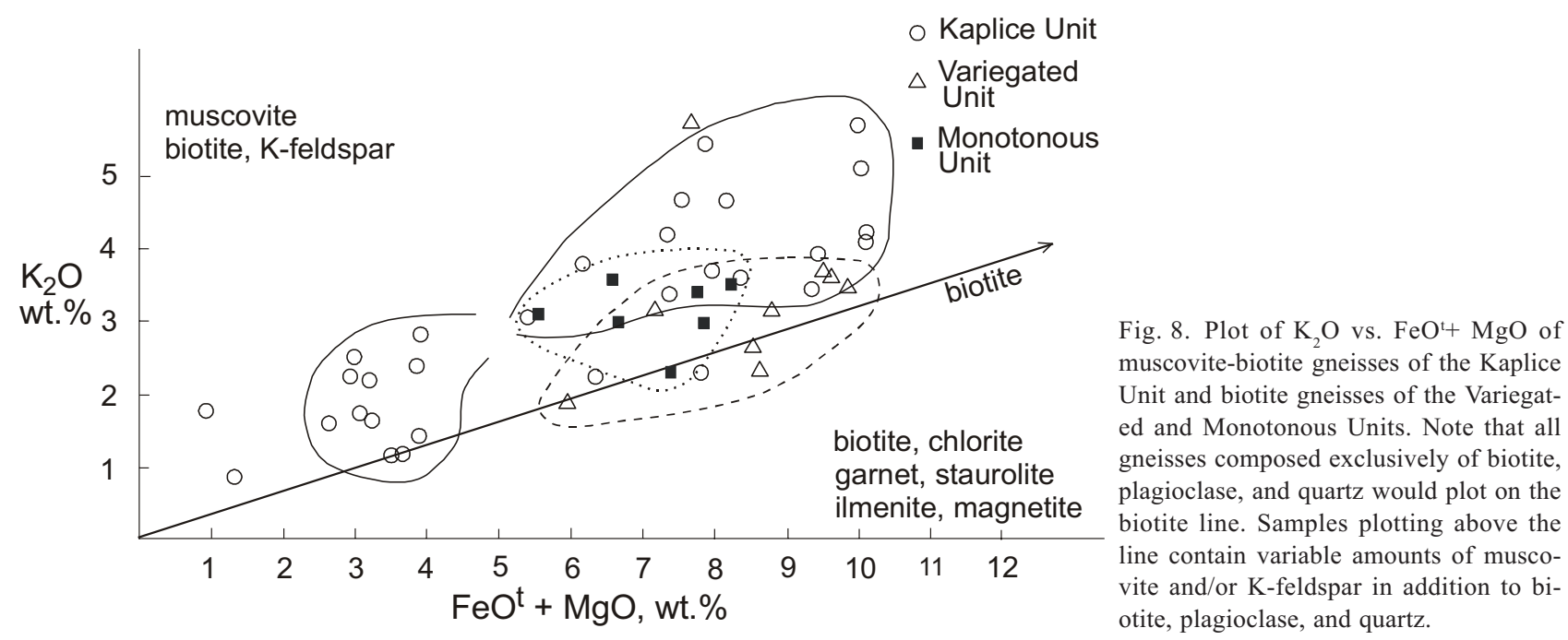

Minor and trace elements were analyzed in 15 samples. They are compared with 11 samples from the Variegated Unit and 8 samples from the Monotonous Unit in terms of normative Ab, Or and An (Fig. 7). The samples from the Kaplice Unit form three major clusters that are designated for convenience as high-K, high-Na, and highCa groups. The term "high" has a purely relative meaning with reference to our set of analyses and relative abundances of $\mathrm{K}_{2} \mathrm{O}, \mathrm{Na}_{2} \mathrm{O}$, and $\mathrm{CaO}$. Mica-rich gneisses plot as a well-defined group of high-K rocks that are distinct from other Moldanubian gneisses in adjacent areas, mainly owing to a high content of muscovite (Fig. 8). In quartzitic gneisses and quartzites, there is no simple correlation between $\mathrm{Na}, \mathrm{Ca}$, and $\mathrm{K}$ contents and the content of $\mathrm{SiO}_{2}$. Several samples of quartzitic gneisses with 79 to 88 wt.\% $\mathrm{SiO}_{2}$ are split mainly between high-Ca and high-Na types; three samples of the high-Ca group represent actinolite-bearing quartzitic gneiss to quartzite.

Table 4 shows calculated average contents of major, minor, and trace elements for the three compositional groups. The bulk average composition of the high-K group shows for several major elements concentrations similar to the average for paragneisses of the Variegated Unit (Table 4, column V-Unit). The data are compared in Figs 9 and 10 with element abundances in gneisses of the adjacent Monotonous and Variegated Units, with the aim to define respective chemical differences. $\mathrm{K}, \mathrm{Rb}, \mathrm{Cs}$, $\mathrm{Ba}, \mathrm{H}_{2} \mathrm{O}^{+}$and $\mathrm{Fe}_{2} \mathrm{O}_{3} / \mathrm{FeO}$ are significantly enriched and
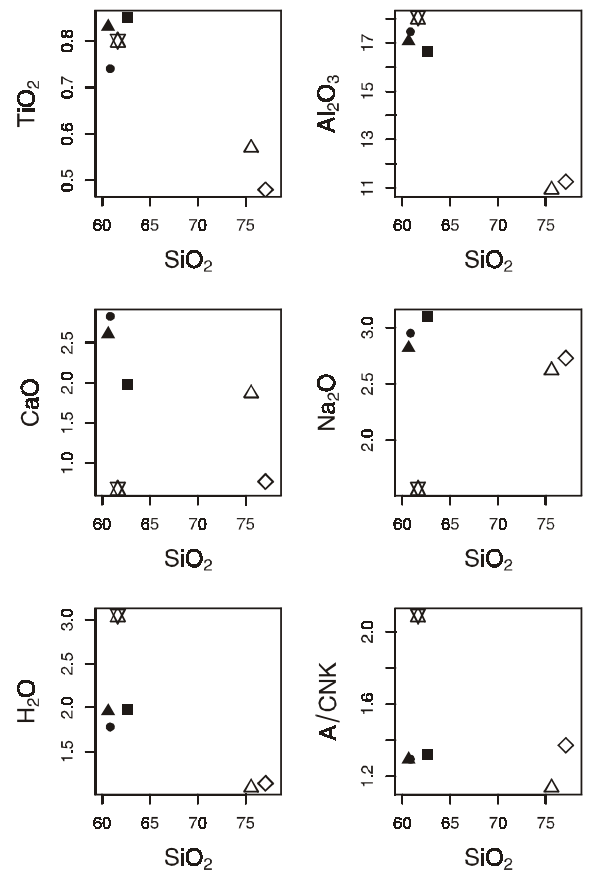
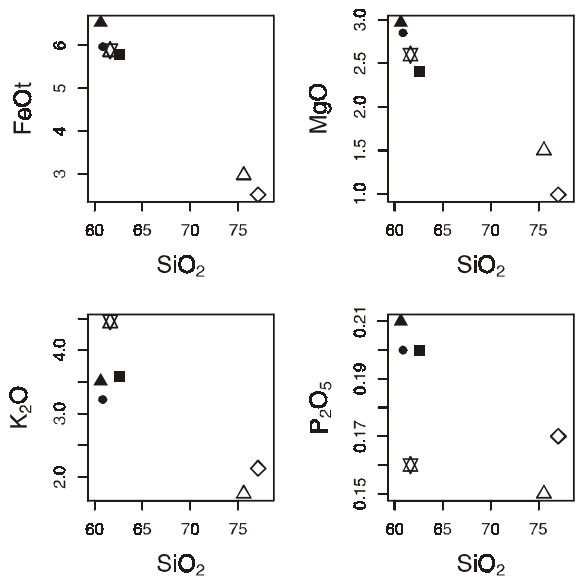

* High-K gneisses (n 12)

$\triangle$ High-Ca gneisses (n 7)

$\diamond$ High-Na gneisses (n 7)

- Variegated Unit (n 11)

- Paragneisses EM (n 11)

- Paragneisses CS (n 12)
Fig. 9. Harker plots of major element oxides and $\mathrm{A} / \mathrm{CNK}$ values for three compositional groups of gneisses from the Kaplice Unit, compared with three sets of paragneisses from the Variegated and Monotonous Units (see text for details of the sample sets). 
Fig. 10. Trace element and $m g$ vs. $\mathrm{SiO}_{2}$ plots for three compositional groups of gneisses from the Kaplice Unit, compared with data for paragneisses from the Variegated Unit.
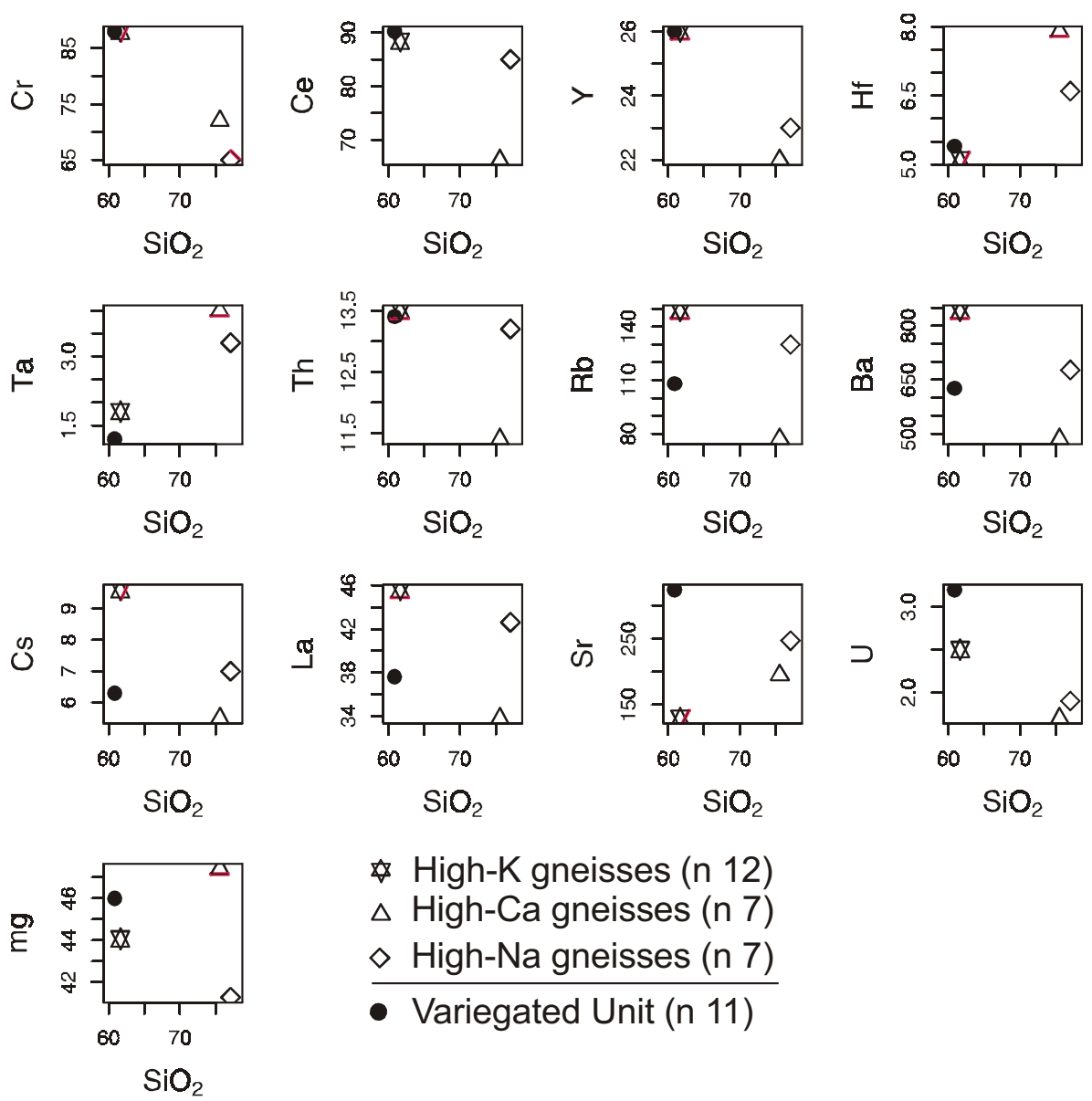

* High-K gneisses (n 12)

$\triangle$ High-Ca gneisses (n 7)

$\diamond$ High-Na gneisses ( $\mathrm{n} 7)$

- Variegated Unit (n 11)

$\mathrm{SiO}_{2}$

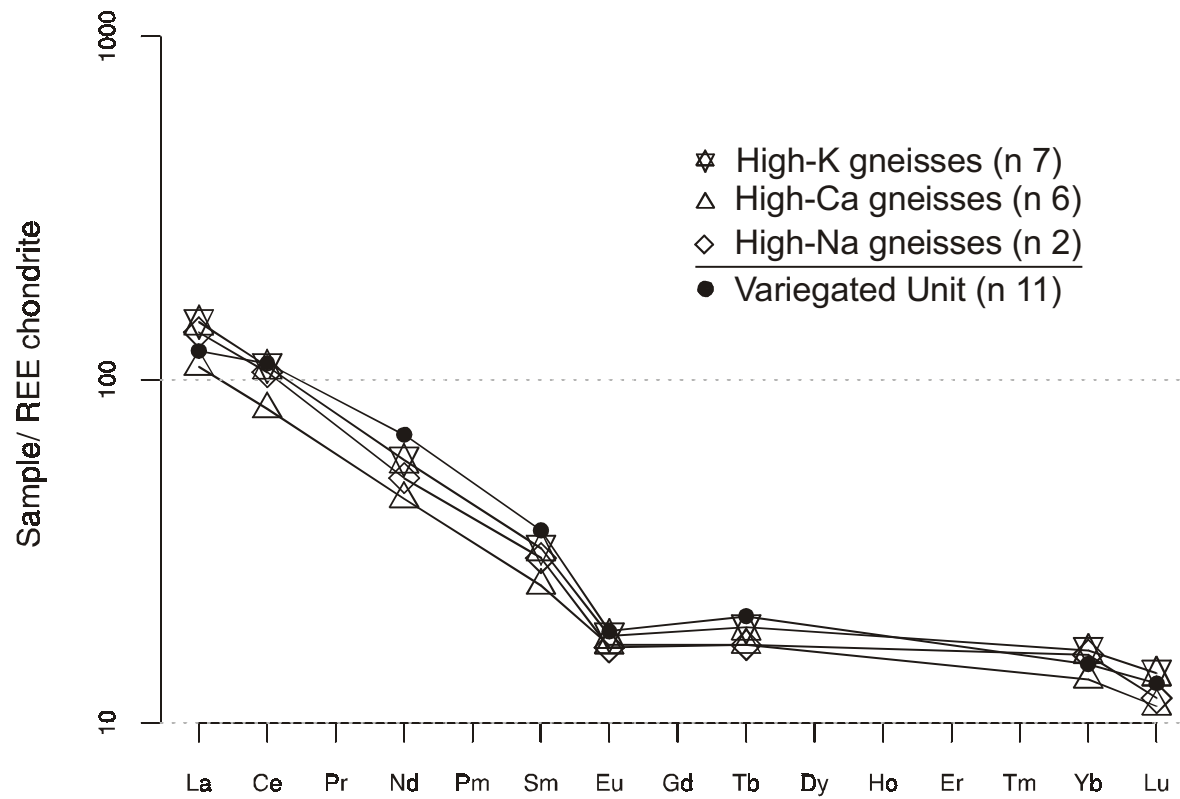

Fig. 11. Chondrite-normalized REE values (Boynton 1984) for three compositional groups of gneisses from the Kaplice Unit compared with data for paragneisses from the Variegated Unit. 
$\mathrm{Na}, \mathrm{Ca}, \mathrm{Sr}, \mathrm{P}$ and $\mathrm{U}$ are distinctly depleted in muscovitebiotite gneisses of the Kaplice Unit; the ratio $\mathrm{Rb} / \mathrm{Sr}$ increased by a factor of 3.5. The contents of Ti, Al, Fe', $\mathrm{Mg}, \mathrm{Cr}, \mathrm{Ce}, \mathrm{Y}, \mathrm{Hf}$, Ta and Th are closely comparable, which corresponds to behaviour of relatively immobile elements. The REE abundances for the three compositional types of Kaplice gneisses and for gneisses of the Variegated Unit are closely similar (Fig. 11). The GCDkit software (Janoušek et al. 2003) was used for comparison of chemical data and their presentation in diagrams.

\section{Discussion}

Mineral composition and retrograde reactions

Variation in biotite composition in muscovite-biotite gneisses as compared to sillimanite-biotite gneisses indicates significant differences in metamorphic conditions. Titanium in the muscovite-biotite gneisses carrying lowTi biotite is contained in part in accessory ilmenite. Comparable ilmenite is normally absent in sillimanite-biotite gneisses of the Monotonous Unit, which contain Ti mainly in Ti-rich biotite. The trend of biotite compositions to low $\mathrm{Ti}$ and high $\mathrm{Al}^{\mathrm{VI}}$ contents, shown most clearly by a sample with strong D4 crenulation (Fig. 5), is typical for retrogressive evolution of the Kaplice gneisses.

The following reactions are responsible for transformation of the original (higher-temperature) sillimanite $+\mathrm{K}$-feldspar amphibolite-facies gneisses to muscovite-biotite gneisses:

garnet $+\mathrm{K}$-feldspar $+\mathrm{H}_{2} \mathrm{O} \rightarrow$ biotite + sillimanite +2 quartz

$\mathrm{K}$-feldspar + sillimanite $+\mathrm{H}_{2} \mathrm{O} \rightarrow$ muscovite + quartz

The reaction (3) is indicated by:

- relative rarity of garnet which is present in minority of samples,

- the presence of fibrolitic sillimanite-biotite and sillimanite-quartz intergrowth structures, corresponding to coeval crystallization of the minerals as indicated by the reaction (3),

- the rarity or absence of $\mathrm{K}$-feldspar,

- the abundance of quartz segregation lenses.

The reaction (4) is indicated by:

- folded fibrolitic sillimanite aggregates overgrown by and enclosed in muscovite and by various stages of fibrolite replacement by fine muscovite,

- the rarity or absence of sillimanite in muscovite-rich samples,

- the rarity or absence of K-feldspar,

- the abundance of quartz segregation lenses.

\section{Chemical changes}

In evaluating the chemical changes superimposed on the original gneiss compositions associated with the D3/M3 and D4/M4 events, it is realized that the original (preD3) compositions remain uncertain in part. Nevertheless, information on the little mobile to immobile elements (Ti, $\mathrm{Al}, \mathrm{Fe}^{\mathrm{t}}, \mathrm{Mg}, \mathrm{Cr}, \mathrm{Ce}, \mathrm{Y}, \mathrm{Hf}, \mathrm{Ta}, \mathrm{Th}$, and REE) indicates that paragneisses of the Moldanubian Zone in proximity of the Kaplice Unit can be considered as rocks close in composition to the original compositions of gneisses of the Kaplice Unit. The interpreted changes in concentrations of some elements are summarized in Figs 9 and 10 on the basis of comparison of average composition of the Variegated Unit gneisses and high-K gneisses. $\mathrm{H}_{2} \mathrm{O}^{+}$, $\mathrm{Fe}_{2} \mathrm{O}_{3} / \mathrm{FeO}, \mathrm{K}, \mathrm{Rb}, \mathrm{Cs}$ and $\mathrm{Ba}$ are significantly enriched and $\mathrm{Na}, \mathrm{Ca}, \mathrm{Sr}, \mathrm{P}$ and $\mathrm{U}$ are distinctly depleted. The ratios of depletion or enrichment for individual oxides and elements are summarized in Table 7. Comparison of $\mathrm{Rb}$, $\mathrm{Cs}$ and $\mathrm{Ba}$ abundances in the three gneiss types shows that these elements are enriched in the high-K gneisses by a similar factor as $\mathrm{K}$. Depletion in $\mathrm{Sr}$ is indicated by comparison of $\mathrm{Ca} / \mathrm{Sr}$ and $\mathrm{Rb} / \mathrm{Sr}$ ratios in high-K and Variegated Unit gneisses. The $\mathrm{CaO}$ contents, when compared to other Moldanubian gneisses, also suggest depletion in calcium. The higher $\mathrm{Zr}$ abundances in high-Ca and high$\mathrm{Na}$ gneisses, in comparison to high-K gneisses, probably indicate a role of size-sorting and resistance to weathering in accumulation of detrital zircon, as the former two types have significantly elevated quartz content.

Petrological information on metamorphic reactions (1) to (4), which indicate significant hydration and muscovitization, and also structural information, give important support for the role of chemical changes accompanying shearing and recrystallization.

Independently of mineralogical and structural criteria, the chemical data provide basis for consideration of a retrograde metamorphic event as indicated by superimposed chemical alterations induced by a high-rate fluid flux. The regional shear zone, coinciding with the Kaplice Unit and its pervasive planar refoliation structure, appears to have functioned as a higher-permeability focussed flow channel (Thompson - Connolly 1992). The high-rate fluid flux aided in pressure solution and fabric re-orientation processes. Under the conditions of a low-T part of amfibolite-facies, a fraction of fluids was conserved in retrograde (hydration) reactions. Well-individualized blasts of chlorite and small-scale intergrowth of chlorite with biotite significantly contribute to the high water content of 3.05 wt. $\%$ in K-rich gneisses. This sit-

Table 7. Ratios of oxides and elements in high-K gneisses of the Kaplice Unit and gneisses of the Variegated Unit.

\begin{tabular}{|c|c|c|c|c|c|c|c|}
\hline \multicolumn{4}{|c|}{$\begin{array}{c}\text { Ratios } \\
\text { near unity }\end{array}$} & \multicolumn{2}{|c|}{$\begin{array}{l}\text { Significant } \\
\text { enrichment }\end{array}$} & \multicolumn{2}{|c|}{$\begin{array}{c}\text { Significant } \\
\text { depletion }\end{array}$} \\
\hline $\mathrm{SiO}_{2}$ & 1.01 & & 0.98 & $\mathrm{H}_{2} \mathrm{O}^{+}$ & 1.71 & $\mathrm{CaO}$ & 0.24 \\
\hline $\mathrm{TiO}_{2}$ & 1.08 & & 0.98 & $\mathbf{K}_{2} \mathbf{O}$ & 1.38 & $\mathrm{Na}_{2} \mathrm{O}$ & 0.53 \\
\hline $\mathrm{Al}_{2} \mathrm{O}_{3}$ & 1.03 & & 1.00 & $\mathbf{R b}$ & 1.38 & $\mathrm{P}_{2} \mathrm{O}_{5}$ & 0.80 \\
\hline FeOt & 1.04 & Hf & 0.94 & $\mathbf{B a}$ & 1.35 & Sr & 0.40 \\
\hline MnO & 0.83 & Th & 1.01 & Cs & 1.52 & $\mathbf{U}$ & 0.78 \\
\hline \multirow[t]{3}{*}{ MgO } & 0.91 & & & A/CNK & 1.60 & & \\
\hline & & & & $\mathrm{Fe}_{2} \mathrm{O}_{3} / \mathrm{FeC}$ & 2.06 & & \\
\hline & & & & $\mathbf{R b} / \mathbf{S r}$ & 3.49 & & \\
\hline
\end{tabular}


uation suggests that retrogression continued in upper greenschist facies, into chlorite stability field during recrystallization accompanying D4 crenulation. Chlorite growth of the type described is different from a younger, superimposed and relatively locallized hydrothermal chlorite production, such as associated with brittle, cataclastic deformation in the Kaplice-Rödl fault zone.

The following indications of a high hydrous fluid flux are notable:

(1) "hydrous" mineral assemblages are prevalent in muscovite-biotite gneisses and result in relative rarity of garnet that is present only in accessory amounts in minority of samples,

(2) calc-silicate gneisses with the early assemblage diopside + calcic plagioclase transformed to actinolite + + plagioclase + clinozoisite ( \pm garnet) assemblage provide evidence of a retrograde hydration,

(3) the abundance of quartz segregation lenses, occassionally with large crystals of andalusite (individual crystals up to $15 \mathrm{~cm}$ long, aggregates up to $70 \mathrm{~cm}$ long), cordierite (rare, up to $25 \mathrm{~cm}$ long), kyanite (individual crystals to $20 \mathrm{~cm}$, aggregates up to $50 \mathrm{~cm}$ long), rutile (rare, up to $16 \mathrm{~cm}$ long); the largely sheet-like quartz lenses are oriented parallel S3; the presence of the enumerated minerals in addition to quartz indicates their formation under respective metamorphic conditions; significant quantities of fluids were instrumental in local accumulation of some elements ( $\mathrm{Si}, \mathrm{Al}, \mathrm{Ti}$ ),

(4) slightly increased boron abundances, compared to gneisses of the Monotonous Unit, are indicated by common accessory tourmaline in muscovite-biotite gneisses of the Kaplice Unit. Localized boron metasomatism resulted in transformation of gneisses to nearly monomineralic tourmalinites, which inherited planar fabric after the parent gneisses (Žáček - Vrána 1999). Such tourmalinites are distinct from somewhat later, discordant, fracture- and breccia-impregnating veins and tourmalinequartz aggregates. The widespread accessory tourmaline can be considered as a geochemical signature indicating a probable granitic source of the fluids operating in retrogression.

The extensive hydration was accompanied by significant oxidation and other chemical changes comparable to synmetamorphic acid leaching.

\section{Sr isotopes}

Assuming a closed system behaviour of muscovite-biotite gneisses of the Kaplice Unit, Zoubek et al. (1977) interpreted $\mathrm{Rb}-\mathrm{Sr}$ isotope analyses on five whole-rock samples to the age of $523 \pm 38 \mathrm{Ma}$, considered as the age of regional metamorphism. Based on average $\mathrm{Rb}$ (142 ppm) and $\mathrm{Sr}(187 \mathrm{ppm})$ contents, a maximum pre-metamorphic age was calculated approximately to $600 \mathrm{Ma} \cdot{ }^{87} \mathrm{Sr} /$ ${ }^{86} \mathrm{Sr}$ in four samples ranges from 0.7268 to 0.7386 and one aberrant sample has ${ }^{87} \mathrm{Sr} /{ }^{86} \mathrm{Sr}=0.7135$. The latter sample contains $101 \mathrm{ppm} \mathrm{Rb}$ and $384 \mathrm{ppm} \mathrm{Sr}$ and thus significantly deviates from the present information on
Sr content (average of $130 \mathrm{ppm} \mathrm{Sr}$ ) in high-K gneisses (Table 4).

For comparison, there is a database of unpublished ${ }^{87} \mathrm{Sr} /{ }^{86} \mathrm{Sr}$ analyses of biotite paragneisses from the Moldanubian Zone north of the Kaplice Unit, in the region between České Budějovice and Tábor. The samples were analyzed by J. Bendl in 1993 in the Laboratory of the Czech Geological Survey. One set of 13 samples gave ${ }^{87} \mathrm{Sr} /{ }^{86} \mathrm{Sr}$ values in the range of $0.7113-0.7287$. The average for 11 samples is 0.7178 (after omission of two samples with the highest ${ }^{87} \mathrm{Sr} /{ }^{86} \mathrm{Sr}$ ratio). Eleven samples from the Soběslav area (Bouška et al. 1985), included in the sample set for the Variegated Unit (Table 4), gave an average of 0.726 . After omission of two marginal high values, the average for 9 samples is 0.7173 .

Compared to the above data sets, the ${ }^{87} \mathrm{Sr} /{ }^{86} \mathrm{Sr}$ values for the four high-K samples from the Kaplice Unit (Zoubek et al. 1977) are rather high and indicate anomality in the $\mathrm{Rb}-\mathrm{Sr}$ system. This can be considered as corresponding to the high increase in $\mathrm{Rb} / \mathrm{Sr}$ ratio in the high-K gneisses in the process of retrogression, the associated influx of $\mathrm{K}, \mathrm{Rb}, \mathrm{Ba}, \mathrm{Cs}$, and a contemporaneous depletion in Sr. Consequently, since the time of ca. 330-320 Ma before present (a probable datum of retrogression and acid leaching), situation in high-K gneisses had switched to increased production of radiogenic Sr.

The abundances of $\mathrm{Rb}$ and $\mathrm{Sr}$ in high- $\mathrm{K}$ gneisses and the major change in $\mathrm{Rb} / \mathrm{Sr}$ ratio indicated by the present study, show, if compared to Moldanubian biotite ( \pm sillimanite) gneisses, that the $\mathrm{Rb}-\mathrm{Sr}$ system is profoundly disturbed (Table 7). Thus, the rocks are not suitable for dating using whole-rock $\mathrm{Rb}-\mathrm{Sr}$ isochron.

The study of the $\mathrm{Rb} / \mathrm{Sr}$ isotope system in granulites of Lower Austria (Arnold - Scharbert 1973) and in sillimanite-muscovite-biotite gneisses and migmatites in the Bohemian-Moravian Upland (Gorokhov et al. 1977) gave results falling in a broad range, including some values similar to data from the Kaplice Unit. The relations could be discussed only on a basis of additional information including details of metamorphic and geochemical histories. Some of the muscovite-biotite gneisses analyzed by Gorokhov et al. (1977) (e.g., Kutná Hora-Svratka Unit) may have experienced similar processes as gneisses of the Kaplice Unit, though the geological setting was probably different in various respects.

\section{Stratigraphy}

Zoubek et al. (1988) suggested that the Kaplice Unit has a status of a stratigraphic unit, the youngest one recognized in the presumed stratigraphic scheme of the Moldanubian Zone of southern Bohemia. This interpretation is invalid in the light of the present evidence for a regional shear zone status of the Kaplice Unit.

The Moldanubian gneisses studied and compared are clearly distinct from the Upper Proterozoic (RipheanVendian) clastic sediments of the Teplá-Barrandian region (Bohemicum) in central and western Bohemia (Bártek 
1979, Cháb et al. 1997), that contain a substantial share of geochemically less evolved (first cycle) detrital material, including intermediate and basic volcani-clastic material. This distinction was already recognized on the basis of major element petrochemical study of the Kaplice Unit.

\section{Possible implications for the origin of other units of muscovite-biotite gneisses in the Moldanubian Zone}

The results from the geochemical study of the Kaplice Unit indicate that a similar approach could be used for clarification of genetic aspects of other units of muscovite-biotite gneisses in the Moldanubian Zone. Koutek (1933) suggested retrogressive origin of muscovite-biotite gneisses of the Rataje Mica Schist Zone at the junction of the Moldanubian Zone and the Kutná Hora Crystalline Complex and Kachlík (1999) presented geochemical evidence on the origin of these muscovite-biotite gneisses by retrogression of Moldanubian biotite paragneisses ( \pm sillimanite). The basic condition for a comparative geochemical study is the preservation of parent equivalent lithologies in proximity and structural evidence of superimposed deformations, which were potentially important for a synmetamorphic fluid flux. Search for and documentation of older relict minerals pre-dating the retrogression, as is the case with calc-silicate gneisses in the Kaplice Unit, is also important.

Acknowledgement. A review of the paper by V. Kachlík, Institute of Geology, Charles University, Prague, brought suggestions resulting in improvement of the paper.

Submitted May 30, 2005

\section{References}

Arnold, A. - Scharbert, H.G. (1973): Rb-Sr Alterbestimmungen an Granuliten der südlichen Böhmischen Masse in Österreich. - Schweiz. Min. Petrogr. Mitt. 53: 61-78.

Babuirek, J. (2003): Polymetamorphic evolution of the Královský hvozd Unit. - Unpublished PhD. Thesis, Masaryk University, Brno, 142 p. (in Czech).

Bártek, J. (1979): The regional metamorphism of the Kaplice series. Unpublished $\mathrm{PhD}$. Thesis, Charles University, Prague, 169 pp. (in Czech).

Bouška, V. - Jelinek, E. - Pačesová, M. (1985): Geochemistry of Moldanubian paragneisses. - Unpublished Research report, Charles University, Praha. (in Czech).

Čech, V. et al. (1960): Explanation to geological map of ČSSR 1 : 200000 M-33-XVII České Budějovice, M-33-XXXIII Vyšší Brod. - NČSAV Praha. (in Czech).

Cháb, J. - Chlupáčová, M. - Manová, M. - Pokorný, L. - Šrámek, J. Vejnar, Z. - Waldhausrová, J. - Žáček, V. (1997): The Teplá-Barrandian Unit. In: Vrána, S. - Štědrá, V. (eds): Geological model of western Bohemia in relation to the ultradeep borehole KTB in FRG. Sborník geologických věd, Geology 47: 80-104.

Gerdes, A. - Friedl, G. - Parrish, R. R. - von Quadt, A. - Finger, F. (2002): U-Pb dating of South Bohemian granites: constraints for the longevity of melting Cadomian crust. - Abstract, Pangeo Austria 2002 - Earth Sciences in Austria, Salzburg, p. 56.

Gorokhov, I. M. - Losert, J. - Varshavskaya, E. S. - Kutyavin, E. P. Melnikov, N. N. - Chekulyaev, V. P. (1977): Rb-Sr geochronology of metamorphic rocks of the eastern part of the Bohemian Massif (Iron
Mountains and the neighbouring part of the Bohemian-Moravian Upland). In: Afanasyev G. D. (ed.): Results of correlation of magmatic and metamorphic rocks. Nauka, Moscow, 81-100. (in Russian).

Janoušek, V. - Farrow, C. M. - Erban, V. (2003): GCDkit: new PC software for interpretation of whole-rock geochemical data from igneous rocks. - Geochemica et Cosmochemica Acta 67, A 186. (Abstracts of the Goldschmidt Conference, Kurashiki, Japan).

Kachlik, V. (1999): Relatioship between Moldanubicum, the Kutná Hora Crystalline Unit and Bohemicum (Central Bohemia, Czech Republic): A result of the polyphase Variscan nappe tectonics. Jour. Czech Geol. Soc., 44: 201-291.

Koutek, J. (1933): Geology of the crystalline complex in proximity of the Sázava River I. Věst. Stát. Geol. Ústavu, 9: 319-353, (in Czech).

Lobkowicz, M. - Štědrá, V. - Schulmann, K. (1996): Late-Variscan extensional collapse of the thickened Moldanubian crust in southern Bohemia. - Jour. Czech Geol. Soc., 41: 123-138.

Kodym, O. (1966): Moldanubicum. - In: Svoboda J. (ed.) Regional geology of Czechoslovakia, I, 40-92, NČSAV, Praha.

Pelc, Z. (1990): Geological map of the Czech Republic 1 : 25 000, sheet 32-411, 413 Přední Výtoň. - Czech Geological Survey, Praha.

Pletánek, Z. - Suk, M. (1976): Notes on stratigraphy and structure of the Moldanubicum in southern Bohemia. - Výzk. práce Ústř. Úst. Geol., Praha, No. 9ú, 28 p. (in Czech).

Šalanský, K. (1967): Regional magnetic zones in the South Bohemian crystalline complex. - Bull. Geol. Surv. Prague, 42: 435-442.

Šalanský, K. - Klein, V. - Domácí, L. (1983): Geophysics. In: Vrána, S. (ed.): Explanation of the geological map of the CSSR $1: 25$ 000, Sheet 32-224 Borovany, pp. 38-43, Czech Geol. Surv. Praha. (in Czech).

Suk, M. (1973): Evolution of chemical composition of metamorphic rocks in the Bohemian-Moravian part of Moldanubicum, Part I. - Unpublished Report, Czech Geological Survey, Prague. (in Czech).

Thompson, A. B. - Connolly, A. D. (1992): Migration of metamorphic fluid: some aspects of mass and heat transfer. - Earth-Science Reviews, 32: 107-121.

Vrána, S. (1979): Polyphase shear folding and thrusting in the Moldanubicum of southern Bohemia. - Bull. Geol. Surv. Prague, 54: 75-86.

- (1992): The Moldanubian Zone in Southern Bohemia: Polyphase evolution of imbricated crustal and upper mantle segments. In: Kukal, Z. (ed.): Proc. $1^{\text {st }}$ Internat. Conference Bohemian Massif, 1988, Czech Geological Survey, Praha, 331-336.

Vrána, S. - Bendl, J. - Buzek, F. (1993): Pyroxene microgranodiorite dykes from the Ševětín circular structure, Czech Republic: mineralogical, chemical, and isotopic indication of a possible impact origin. - Jour. Czech Geol. Soc., 38: 129-146.

Vrána, S. - Blümel, P. - Petrakakis, K. (1995): Moldanubian Zone-Metamorphic evolution. - In: Dallmeyer, R. D. - Franke, W. - Weber, K. (eds): Pre-Permian geology of Central and Eastern Europe, 453-468. Springer-Verlag, Berlin.

Waldmann, L. (1930): Geologische Studien in der Glimmerschieferzone Südböhmens. - Anz. Akad. Wissen., 67: 183-187.

- (1932): Über die Glimmerschieferzone Südböhmens. - Miner. Petrogr. Mitt., 43: 89-91.

Zelenka, L. (1926): Geological study in the Bohemian-Moravian Upland. - Sbor. Geol. Úst., 5: 561-586. (in Czech).

Zoubek, V. - Fiala, J. - Vaňková, V. - Machart, J. - Stettner, G. (1988): Moldanubian Region. - In: Zoubek, V. - Cogné, J. - Kozhoukharov, D. - Kräutner, H. G. (eds): Precambrian in younger fold belts, European Variscides, the Carpathians and Balkans, 183-267. J. Wiley and Sons, Chichester etc., $885 \mathrm{p}$.

Zoubek, V. - Gorokhov, I. M. - Melnikov, N. N. - Chekulayev, V. P. Varshavskaya, E. S. (1977): Rb-Sr age of rocks of the Kaplice Group in the Moldanubicum of southern Bohemia. In: Afanasyev G. D. (ed.): Results of correlation of magmatic and metamorphic rocks. Nauka, Moscow. 73-80. (in Russian).

Žáček, V. - Vrána, S. (1999): Tourmaline of tourmalinites and quartz secretions from the Kaplice Unit (southern Bohemia). - Bull. mineralog.petrolog. Odd. Nár. Muz. (Praha), 7: 233-235. (in Czech). 


\section{Retrográdní metamorfóza muskovit-biotitických rul v kaplické jednotce moldanubika jižních Čech a sdružené chemické změny}

Práce předkládá výsledky geochemického a petrologického studia muskovit-biotitických rul kaplické jednotky na základě analýz hlavních prvkủ ve 30 vzorcích a stopových prvků v 15 vzorcích. Data jsou porovnána s obsahy v rulách jenotvárné a pestré jednotky. V rulách kaplické jednotky jsou obsahy $\mathrm{K}, \mathrm{Rb}, \mathrm{Cs}, \mathrm{Ba}, \mathrm{H}_{2} \mathrm{O}^{+}$a $\mathrm{Fe}_{2} \mathrm{O}_{3} / \mathrm{FeO}$ výrazně navýšené a obsahy $\mathrm{Na}, \mathrm{Ca}, \mathrm{Sr}, \mathrm{P}$ a $\mathrm{U}$ jsou významně snížené ve srovnání s obsahy v biotitických pararulách jednotvárné i pestré jednotky. Poměr Rb/Sr je vyšší 3,5×. Obsahy Ti, Al, Fet, Mg, Cr, REE, Y, Hf, Ta a Th jsou blízce srovnatelné, což odpovídá vlastnostem prvků s nižší mobilitou. Významná hydratace byla doprovázena oxidací a dalšími synmetamorfními chemickými změnami, podobnými procesu kyselého vyluhování. Mikrostrukturní vztahy indikují reakce konzumující sillimanit a K-živec. Hojné sekreční čočky křemene orientované podél ploch regionální stř̌ižné foliace $\mathrm{S} 3$ svědčí o vysoké aktivitě $\mathrm{SiO}_{2}$ uvolněného v retrográdních reakcích. Tyto čočky občas obsahují velké krystaly andalusitu a vzácně kyanitu, cordieritu a rutilu. Souběžné reakce v erlanech zahrnují zatlačování diopsidu aktinolitem nebo magneziohornblendem chudým $\mathrm{Al}$ a částečnou reakci bazického plagioklasu na klinozoisit a akcesorický granát. Strukturní a petrologická data indikují, že kaplická jednotka představuje regionální zónu střižných deformací (D3) s funkcí vysokého synmetamorfního př́ikonu fluid. Protože kaplická jednotka je v přímém nadloží plutonu muskovit-biotitického granitu typu Eisgarn, který je poněkud mladší než střižná foliace S3 a starší než krenulační kliváž S4, je pravděpodobné, že hlavním zdrojem fluid byla krystalizace magmat tohoto plutonu. 
